NBSIR 85-3213

\title{
The Chlorine Content of Municipal Solid Waste From Baltimore County, MD and Brooklyn, NY
}

K.. L. Churney, A. E. Ledford, Jr., S. S. Bruce, and E. S. Domalski

U.S. DEPARTMENT OF COMMERCE

National Bureau of Standards

National Measurement Laboratory

Gaithersburg, MD 20899

April 1985

Issued October 1985

Prepared for

Office of Renewable Technology

Energy from Municipal Waste Division

U.S. Department of Energy

Forrestal Building

1000 Independence Avenue, S.W.

Washington, DC 20585

and

The City of New York

nanortment of Sanitation

$-Q C \_$Resource Recovery and Waste Disposal Planning

100 bers Street, Room 815

.456

$\therefore$ NY 10007 

THE CHLORINE CONTENT OF MUNICIPAL

SOLID WASTE FROM BALTIMORE

COUNTY, MD AND BROOKLYN, NY

K. L. Churney, A. E. Ledford, Jr., S. S. Bruce, and E. S. Domalski

U.S. DEPARTMENT OF COMMERCE

National Bureau of Standards

National Measurement Laboratory

Gaithersburg, MD 20899

April 1985

Issued October 1985

Prepared for

Office of Renewable Technology

Energy from Municipal Waste Division

U.S. Department of Energy

Forrestal Building

1000 Independence Avenue, S.W.

Washington, DC 20585

and

The City of New York

Department of Sanitation

Office of Resource Recovery and Waste Disposal Planning

51 Chambers Street, Room 815

New York, NY 10007

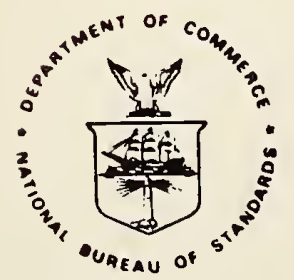

U.S. DEPARTMENT OF COMMERCE, Malcolm Baldrige, Secretary NATIONAL BUREAU OF STANDARDS, Ernest Ambler, Director 



\section{TABLE OF CONTENTS}

Page

Abstract ....................... . . 1

1.0 Introduction . . . . . . . . . . . . . . . 2

2.0 Sampling Municipal Solid Waste . . . . . . . . . 3

2.1 Collection, Sorting, and Sample Preparation

Baltimore County, MD . . . . . . . . . . 3

2.2 Collection, Sorting, and Sample Preparation,

Brooklyn, NY ................... 6

3.0 Experimental Results . . . . . . . . . . . . 10

3.1 Baltimore County, MD ............ 10

3.2 Brooklyn, NY . . . . . . . . . . . . 13

3.3 Comparison of Experimental Results . . . . . . . 16

4.0 Summary and Conclusions . . . . . . . . . . 18

4.1 General . . . . . . . . . . . 18

4.2 Baltimore County, MD ........... 18

4.3 Brooklyn, NY .............. 20

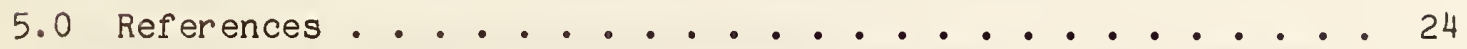

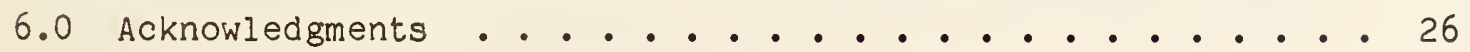

Appendix Definitions of Statistical Parameters . . . . . . 27 


\section{LIST OF TABLES}

Table 1. Average Composition of Municipal Solid Waste Obtained from the Baltimore County Resource Recovery Facllity, Cockeysville, MD during January, 1983.

Table 2. Composition of Municipal Solid Waste Obtained 10, 11, 12, 19, 21 January, 1983 from the Baltimore County Recovery Facility, Cockeysville, MD.

Table 3. Processing of Waste Components

Table 4. Composition and Chlorine Content of Composite Samples, Baltimore County, MD

Table 5. Residual Moisture Content, Baltimore County, MD

Table 6. Total Chlorine Content, Baltimore County, MD

Table 7. Water Soluble Chlorine Content, Baltimore County, MD

Table 8. Sulfur Content of Composite Samples, Baltimore County, MD

Table 9. Variability of Total Chlorine Content, Baltimore County, MD

Table 10. Variability of Water Soluble Chlorine content, Baltimore County, MD

Table 11. Summary of Total Chlorine, Water Soluble Chlorine, and Water Insoluble Chlorine Contents, Baltimore County, MD

Table 12. Amount of Chlorine Contributed by MSW Components, Baltimore County, MD

Table 13. Calculated Percent of Chlorine Contributed by Components of Baltimore County MSW to Chlorine Content

Table 14. Average Composition of Municipal Solid Waste Obtained from the Greenpoint Incinerator Facility, Brooklyn, NY during January 1984 (Mass \%, As-Recelved at the Facility)

Table 15. Composition of Municipal Solid Waste Obtained 30 January, 1984 from the Greenpoint Incinerator, Brooklyn, NY.

Table 16. Composition and Chlorine Content of Composite Samples, Brooklyn, NY

Table 17. Residual Moisture Content, Brooklyn, NY

Table 18. Total Chlorine Content, Brooklyn, NY

Table 19. Water Soluble Chlorine Content, Brooklyn, NY

Table 20. Sulfur Content of Composite Samples, Brooklyn, NY 
Table 21. Variability of Total Chlorine Content, Brooklyn, NY

Table 22. Variability of Water Soluble Chlorine Content, Brooklyn, NY

Table 23. Summary of Total Chlorine, Water Soluble Chlorine, and Water Insoluble Chlorine Contents, Brooklyn, NY

Table 24. Amount of Chlorine Contributed to MSW Components, Brooklyn, NY

Table 25. Calculated Percent of Chlorine Contributed by Components of Baltimore County MSW to Chlorine Content 

The Chlorine Content of Municipal. Solid Waste

from Baltimore County. MD and Brooklyn, NY

K.L. Churney, A.E. Ledford, Jr., S.S. Bruce, and E.S. Domalski Chemical Thermodynamics Division

Center for Chemical Physics

National Bureau of Standards

Gaithersbur 8, MD 20899

\section{Abstract}

The total chlorine and water soluble chlorine contents of the components of municipal solid waste (MSW) have been determined from sampling studies carried out at two sites, Baltimore County, MD, and Brooklyn, NY, for a five-day period. The total chlorine contents of the overall MSW samples at Baltimore County, MD, and Brooklyn, NY, are 0.45 and 0.89 mass \%, respectively.

The component which contributed the largest fraction to the chlorine content in Baltimore County, MD, was the paper fraction $(0.25$ mass \% or $56 \%$ of the total chlorine) while in Brooklyn, NY, the plastics fraction provided the major contribution ( 0.46 mass \% or $52 \%$ of the total chlorine). Chemical analyses for sulfur content were also performed on composite samples for each day of sampling at the two sites. The sulfur contents found in composite samples representing Baltimore County, MD, and Brooklyn, NY, were 0.13 and 0.14 mass \%, respectively. American Society for Testing and Materials (ASTM) standard methods for sulfur, total chlorine, and water soluble chlorine contents, developed for refusederived fuel, were used in performing the analyses.

All values mentioned above in mass $\%$ are on a dry basis. 


\section{Introduction}

During the late 1970 's and early 1980 's, polychlorinated dibenzo-p-dioxins (PCDD's) and polychlorinated dibenzofurans (PCDF's) have been found in the precipitator fly ash and flue gas of a number of incinerator facilities in the U.S. and Europe in the parts per billion to parts per trillion range [1-9]. The resulting public alarm has seriously slowed or even stopped the construction or operation of waste-to-energy plants. In order to understand the reason for the presence of chlorinated organic pollutants in the precipitator fly ash or flue gas of incinerator facilities, an analysis for the chlorine content of each component of the input waste stream is needed. Examination of the literature showed that a study of the distribution of chlorine content among the components of municipal solid waste (MSW) had been carried out in Central wayne County, MI in August of 1979 [10]. The data in that study consisted of the chlorine content of the textile/garment and plastic fractions of MSW for a five day period as well as data on the chlorine content of all waste components from one day's sampling. Examination of their results suggested that a more comprehensive study of the chlorine content of MSW was warranted. Hence, during the past year, a total chlorine and water soluble chlorine content study was carried out by NBS over a five day period on MSW from each of two sources: Baltimore County, Maryland, and Brooklyn, New York.

The results of the two studies are presented in this report. Some definitions of elementary statistical parameters are provided in an appendix . 


\subsection{Sampling Municipal Solid Waste \\ 2.1 Collection, Sorting, and Sample Preparation,}

Baltimore County, MD

Thirteen to twenty-three kilograms of $\mathrm{RDF}^{-2^{1}}$ were obtained on 5 working days (January 10, 11, 12, 19, 21, 1983) from the Baltimore County Resource Recovery Facility in Cockeysville, Maryland. Each sample was removed from the conveyor belt immediately after the primary shredder, but before any further processing occurred. Only one sample was taken from the conveyor belt each day. The material was brought to NBS on the same day, dried for 12 hours at $105{ }^{\circ} \mathrm{C}$ to determine its total moisture content, and then stored at $5^{\circ} \mathrm{C}$. We assumed that no moisture was lost in transit because samples were triple bagged. Each day's material was hand sorted into eight categories. The categories were: paper, soft (film) plastics, hard (rigid) plastics, wood/vegetable matter, textiles, "fines" (sweepings), glass/ceramics, and metals.

The average composition of MSW obtained from Baltimore County, MD is provided in table 1 for each of the separated components in mass $\%$ on an as-received basis at the facility and the dally composition of the MSW is given in table 2. In table 2, the first row gives the total moisture content on an as-received basis at the facility and rows 2 to 8 show the mass percent of each waste component on a dry basis. Rows 9 to 10 give the composition according to combustible content (the sums of paper, soft

Refuse-derived fuel-2, RDF-2, is MSW that has been processed to reduce the particle size so that 95 mass-percent passes through a $15 \mathrm{~cm}$ square mesh. 
plastics, hard plastics, wood/vegetable matter and textiles), and noncombustible content (metals, glass/ceramics, and "flnes"), also on a dry basis.

Each category except for metals and glass/ceramics for each day's material was processed to $2 \mathrm{~mm}$ particle size or less and blended as described in table 3. As indicated in the second column, all components except paper required some initial processing. Dry ice was used, in the final particle size reduction of plastics, wood/vegetable, and textiles to prevent jamming of the milling equipment. Four milling machines were used to carry out the size reduction of the waste components; a Williams Hammer Mill2 (Model GP-1512, Williams Patent Crusher and Pulverizer Co.), a Wiley Mill (No. 4, model S-60982, Sargent-Welch Co.), and two Brinkmann Instrument Co. Mills (Models SR-3 and ZM-1). The Williams Hammer Mill was used in the initial processing of the hard plastics and in the final reduction of the paper. The cutting action of the wiley Mill was found to be most suitable for the final reduction of the wood/vegetable and textiles components. A rotor-beater mill (Brinkmann Instrument Co., Model SR-3) was used in the final reduction of the soft and hard plastic components. A centrifugal grinding mill (Brinkmann Instrument Co., Model ZM-1) was used in the final reduction of the "fines" component. The SR-3 mill is similar to the ZM-1 mill in its principle of operation but is better suited for processing large quantities of softer materials than the $\mathrm{ZM}-1 \mathrm{mill}$.

2 The commercial sources cited in this paper are included to adequately describe the experimental procedures. Such identification does not imply recommendation or endorsement by the National Bureau of Standards. 
The processed components were stored at $5^{\circ} \mathrm{C}$ in glass or polyethylene bottles except for the paper which was stored in large double polyethylene bags. After blending each of the components, samples were removed from each of the components for total chlorine analysis (three samples, each about $2 \mathrm{~g}$ ), water soluble chlorine analysis (three samples, each between 3.5 to $5 \mathrm{~g}$ ), residual moisture determinations (two samples, each about 2 $\mathrm{g})$, and a reserve for use in later tests.

The processing of MSW components to $2 \mathrm{~mm}$ particle size increases the surface area of the sample making it more susceptible to the adsorption of moisture from the air. Consequently, a second moisture determination is necessary and called residual moisture. The residual moisture is smaller in magnitude ( 3 to 5 mass $\%$ ) than the original total moisture (20 to 26 mass \%). The residual moisture determinations are usually performed concurrently with other analyses, such as chlorine or sulfur, so that calculation to a dry basis is possible.

In this study, the processed components of MSW were not analyzed separately for sulfur content. However, triplicate sulfur determinations were carried out on a composite sample.

A composite sample having a mass of about 42 grams was prepared from each day's components. The composite sample had almost the same composition as the original waste exclusive of the glass/ceramics and metal fractions. It was prepared from the reserve fractions in appropriate proportions assuming that each separate component was totally dry. Thereafter, duplicate residual moisture determinations were performed on each of the components and the moisture data were used to correct the composition of the composite sample to a dry basis. Also, the 
residual moisture was determined for the composite sample itself so that the corresponding analyses for total chlorine, water soluble chlorine, and sulfur content could be adjusted to a dry basis.

The composite sample was blended by end-over-end tumbling in a polyethylene bottle for twenty-four hours. It was then subdivided into test samples using a Brinkmann Instrument Co. Sample Divider PTZ to obtain samples for total chlorine, water soluble chlorine, residual moisture, and total sulfur analyses. Our previous study on assessing the credibility of the calorific value of MSW [11] showed that sample subdivision by this method gives aliquots that are representative even though the sample is heterogeneous.

The samples of individual components as well as the composite sample for each type of analysis were analyzed in random order; the entire contents of each sample (e.g., 2 grams for an individual chlorine analysis) was used in a single measurement. Chlorine, sulfur, and residual moisture analyses were carried out according to ASTM standard methods: E776-81, Total Sulfur in the Analysis Sample of Refuse-Derived Fuel; E775-81, Forms of Chlorine in Refuse-Derived Fuel; and E790-81, Residual Moisture in a Refuse-Derived Fuel Analysis Sample, respectively. The determinations for chlorine, sulfur, and residual moisture were performed at Gascoyne Laboratories, Inc., Baltimore, MD for both Baltimore County, MD and Brooklyn, NY. 


\subsection{Collection, Sorting, and Sample Preparation, Brooklyn, NY}

Sampling of MSW at the Greenpoint Incinerator Facility was carried out on five consecutive days from January 30 through February 3, 1984. The total number of increments withdrawn and mass per increment were selected on the basis of ASTM Committee E-38 provisional document EDS-18, which is based on ASTM method D 2234, "Collection of a Gross Sample of Coal." The mass per increment was chosen to correspond to the "unit" size of the MSW as-received in a "jiffy" or nominal trash bag. The total number of increments was set by the mass per increment and the maximum mass allowed by our working and storage space at NBS, $227 \mathrm{~kg}$ (500 Ibs).

After examining the ASTM's provisional document EDS-18, we decided to withdraw 35 increments for the week, 7 increments each day with each increment of about $7 \mathrm{~kg}(15 \mathrm{lb})$ mass.

In practice a total of 29 increments were withdrawn for the week rather than the planned 35; the number of increments per day ranging from 5 to 7. Each of the increments was withdrawn at as nearly the same time each day as circumstances permitted. The actual withdrawal times for each day were as follows:

\section{COLLECTION TIMES}

Increments

DATE Collected
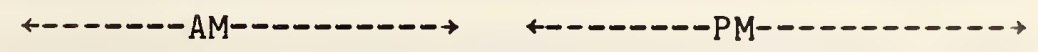

$1 / 30$

$$
5
$$

$--\quad 10: 30$

$11: 40$

$12: 00$

$--\quad 1: 45 \quad 3: 15$

$1 / 31$

6

$9: 40$

$10: 30$

$11: 00$

$12: 00 \quad 12: 45 \quad \ldots \quad 3: 00$

$2 / 1$

7

$10: 00$

$10: 50$

$11: 30$

$12: 10$

$1: 002: 10 \quad 3: 00$

$2 / 2$

6

$10: 00$

$11: 00$

$11: 45$

$-$

$12: 452: 00$

$2: 50$

$2 / 3$

5

$10: 00$

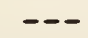

$12: 20$

$1: 20 \quad 1: 45 \quad 3: 00$ 
In our initial sampling plan, the crane operator would be told to $\mathrm{mix}$ the contents of two or more dump truck loads in the bottom of the dumping pit by repeated picking up and dropping of parts of the load with the grapple hook. He then would pick up a grapple hook load of the "mixed" waste and drop it in the area used to pile noncombustible bulky materials. The amount of mixed waste dumped was supposed to be between $41 \mathrm{~kg}$ (90 Ibs) and $82 \mathrm{~kg}$ (180 lbs). The pile would then be divided into equal parts by a grid. The parts should each contain about $7 \mathrm{~kg}$ (15 lbs) and the geometrical location of the grid should be fixed relative to the dropping area.

In practice, sampling was limited to between 9:00 AM and 3:00 PM. The day shift started at 8:00 AM. Truck deliveries ceased after 3:00 PM, or so, for the day shift and resumed after 7:30 PM for the next shift. The method of collecting and preparing an increment had to be modified since It was discovered on arrival that the grapple hook design precludes the pickup of less than a full load (greater than 300 cu. ft., about 1500 Ibs). No space or equipment (such as a front loader) was avallable to spread a full load in order to pull out an increment (about 15 lbs). The following substitute procedure was immediately developed and Implemented.

Increments were prepared by sampling the contents of two or more delivery trucks. As each truck dumped its load into the receiving pit, the storage bags which contained most of the MSW broke open, and part of the load spilled over on to the actual traffic area in front of the recelving pit. This spillover was collected provided it did not appear to be grossly different from the bulk of the truck's contents (e.g. by visual comparison with the bulk dropped into the bottom of the pit). Otherwise 
the material was discarded and the next truck was sampled and so on. Hospital refuse was not included in the collection because of the potential health hazard. Some types of MSW (e.g., tapes and files of legal evidence) could not be included because this is prohibited by the New York City Police. Construction materials and ash (1e. from tenemant buildings), which are sometimes dumped into the pit, were not included since this material is normally dumped into barges and then transported to a landfill.

Sample increments were triple bagged, dried at NBS for 12 hours at $105^{\circ} \mathrm{C}$ to determine their total moisture content, and then stored at $5^{\circ} \mathrm{C}$. Thereafter, each increment was hand-sorted into nine categories: unbleached paper, bleached paper, soft (film) plastics, hard ( $r i g i d$ ) plastics, wood/vegetables, textiles, metals, glass/ceramics, and "fines" (sweepings). The corresponding components of the increments of the same day were then combined. The average composition of MSW at Brooklyn's Greenpoint Incinerator is given in table 14. The corresponding daily composition is shown in table 15.

Each category except for metals and glass/ceramics for each day's material was processed to $2 \mathrm{~mm}$ particle size or less and blended as described in table 3. Thereafter, the processing procedures for the Brooklyn samples were identical to those used for the Baltimore county samples with respect to the choice of milling machines, blending, preparation of a composite sample, sub-sampling, bottling, and storage. Similarly, analyses for total chlorine, water soluble chlorine, sulfur, and residual moisture were carried out using the corresponding ASTM methods mentioned earlier. 


\subsection{Experimental Results}

\subsection{Baltimore County, MD Results}

The results of the analyses for the Baltimore County, MD study are given in tables 4 through 8 . Table 4 provides data on the composition and chlorine content of the prepared composite sample and also gives the corresponding values derived from the original composition of the waste in Table 1 and the chlorine content data in table 6. The purpose of the "measured" and "calculated" columns for each day in Table 4 is to show that the earlier assumption of the "dryness" of the components was acceptable in the preparation of the composite samples. The smallness of the differences between the measured and calculated values suggested that good control prevalled during the preparation and chlorine analyses of the composite samples assuring their representativeness.

Table 5 gives data on duplicate determinations for residual moisture and the corresponding average value. Triplicate determinations for total chlorine and water soluble chlorine content can be found in tables 6 and 7 along with the average values on both an as-received and dry basis. Table 8 provides triplicate determinations for the sulfur content of the composite samples and the average value on both an as-received and dry basis. It is evident that the sulfur content of the Baltimore Count MSW is quite low.

An analysis of the variability of the total chlorine and water soluble chlorine contents was carried out using standard statistical methods $[12,13]$. Results are summarized in tables 9 and 10 . The percent coefficient of variation, \% C.V., for the within-day variability of the total chlorine content is less than the between-day variablitty for all 
waste components except for the paper. The approximate equality of the corresponding within and between-day variabilities of the composite samples may be partially due to the large chlorine content of the paper, which constitutes 60 to 70 mass \% of the composite sample (see table 4). The $\%$ C.V. of the within-day and between-day variability of the water soluble chlorine are scattered, showing both high and low values. The relatively large within-day variability of the chlorine content analyses in tables 9 and 10 is probably due to the heterogeneous nature of refuse. The average values on a dry basis in tables 6 and 7 have been rearranged into a breakdown of the total chlorine content of the composite sample and the various components into water soluble and water insoluble chlorine contents. These results are given in table 11 . The water insoluble chlorine content is the total chlorine content minus the water soluble chlorine content. The water insoluble chlorine content has been called "organic" chlorine content but this can be misleading. Some organic chlorides are water soluble and some inorganic chlorides are water insoluble. The first row in table 11 opposite a given component or the composite sample contains the corresponding average on a dry basis total chlorine content listed in table 6 . The second row is the ratio in percent of the corresponding water soluble chlorine content in table 7 divided by the corresponding first row entry. The third row is 100 minus the second row entry. Day averages are given in the far right column. It should be noted that all numbers refer to the composite sample or particular component alone and not the contribution of this component to the overall total, water soluble, or water insoluble chlorine content of each day's material. It can be seen that the water insoluble chlorine content is a 
factor of two to three greater than that of the water soluble chlorine content for the composite sample and all components except for wood/vegetable matter. In the latter component, the water soluble chlorine content is twice that of the water insoluble chlorine content. The calculated contribution of the various components of the waste to the overall total chlorine, water soluble chlorine, and water insoluble chlorine content of each day's material are listed in table 12. It is assumed that the chlorine contents of the glass and metal fractions are negligible. Each day's value for total and water soluble chlorine content was calculated by multiplying the average percent chlorine content on a dry basis of each component in table 6 and 7 by the mass percent of the component in table 2. The water insoluble chlorine content was calculated by difference. One finds that the total chlorine content of the original waste is predominantly $(76 \%)$ water insoluble chlorine according to table 12 .

The percent contribution of the various components of the waste to each day's overall total chlorine, water soluble chlorine, and water insoluble chlorine content of each day's material is listed in table 13. The sums of each column of a given type of chlorine for each day is equal to 100. The percent of the sum of the components averages are listed in the far right column (The latter are not, in general, equal to the average percentages.) On the average, the paper fraction contributed slightly more than half the total chlorine content and four fifths the water soluble chlorine content. The combined plastic fractions contribute about 
one third of the total chlorine content and about two fifths of the water insoluble chlorine content. The "fines" contribute about $10 \%$ of the total, water soluble, and water insoluble chlorine contents.

\subsection{Brooklyn, NY}

The average and daily composition of MSW at Brooklyn's Greenpoint Incinerator are provided in tables 14 and 15, respectively. Care was taken to separate the plastic fraction into soft and hard component as was done with the Baltimore County study. In addition, the paper fraction was divided into bleached and unbleached portions to see if any significance could be attributed to such a separation and the observed values determined for total chlorine and water soluble chlorine. The results of the analyses for the Brooklyn, NY, study are given in tables 16 through 20. Table 16 provides data on the "measured" composition and chlorine content of the prepared composite sample. Also, the corresponding "calculated" values are shown and were derived from the original composition of the waste in table 15 and the chlorine content data in tables 18 and 19. The closeness of agreement between the "measured" and "calculated" columns indicates that the earlier assumption regarding the "dryness" of the components was acceptable in the preparation of the composite samples and that good control prevailed during the preparation and chlorine analyses of the composite samples.

Duplicate determinations and the average values for residual moisture are shown in table 17. Tables 18 and 19 give data on triplicate determinations and average values for both an as-received and dry basis for total chlorine and water soluble chlorine content, respectively. 
Table 20 provides triplicate determinations for the sulfur content of the composite samples and average values on both an as-received and dry basis. Here, as with the Baltimore County study, the sulfur content is quite low. An analysis of the variability of the total chlorine and water soluble chlorine contents was carried out using standard statistical methods $[12,13]$. Results are summarized in tables 21 and 22 . The percent coefficient of variation, \% C.V., for the within-day variability of the total chlorine content is less than the between-day variability for all waste components except for the total chlorine content of the wood/vegetable matter. The greater within-day variability of the latter is due to an apparent outlier in the measurements on day 3 (see table 18). Exclusion of this outlier yields the row of parenthetic values in table 21. The within-day variability of the latter is less than the between-day variability. In table 22 , the $\% \mathrm{C} . \mathrm{V}$. of the within-day variability of the water soluble chlorine is less than the between-day variability for all components except for the water soluble chlorine content of the "fines." Inspection of table 19 suggests that the greater within-day variability of the "fines" in table 22 is not due to a single outlier and, thus, is real. The averages on a dry basis in tables 18 and 19 have been rearranged into a breakdown of the total chlorine content of the composite sample and the various components into water soluble and water insoluble chlorine contents. These results are given in table 23. The water insoluble chlorine content is the total chlorine content minus the water soluble chlorine content. The first row in table 23 opposite a given component or in the composite sample contains the corresponding average total chlorine 
content 1 isted in table 18 in mass percent, dry basis. The second row is the ratio in percent of the corresponding water soluble chlorine content in table 19 divided by the corresponding first row entry. The third row is 100 minus the second row entry. Day averages are given in the far right column. It should be noted that all numbers refer to the composite sample or particular component alone and not the contribution of this component to the overall total, water soluble, or water insoluble chlorine content of each day's material. It can be seen that the water soluble chlorine content of the composite sample tends to be less than a third of the total chlorine content.

Average values for the components given in table 23 suggests that virtually all of the components except the two plastic fractions have roughly equal amounts of water soluble and water insoluble chlorine. Thus, the plastic fractions, both of which contain very little or no water soluble chlorine, cause the water insoluble content of the composite sample to be larger than its water soluble content. This, evidently, is the case even though the mass percent of plastics in the composite samples (see table 16) is only about $20 \%$ of the combustible components.

The calculated values of the total, water soluble, and water insoluble contents of the Brooklyn MSW based on its initial (dry) composition are given in table 24. It is assumed that the chlorine contents of the glass and metal fractions are negligible, although, their presence must be accounted for in calculating the final values for the mass percent of chlorine. Each day's value for total or water soluble shlorine content was calculated by multiplying the percent chlorine content of each component in table 18 and 19 by the mass percent of the 
component listed in table 15. The water insoluble chlorine content value was calculated by difference. One can see that the total chlorine content of the original waste stream is predominantly (76\%) water insoluble chlorine.

The percent contribution of the various components of the waste to each day's overall total chlorine, water soluble chlorine, and water insoluble chlorine content of each day's material is listed in table 25. The sums of each column of a given type of chlorine for each day is equal to 100. The percent of the sum of component averages are listed in the far right column. In general, the latter are not equal to the average percentages. On the average, the combined plastics contribute about one half of the total chlorine content and two thirds of the water insoluble chlorine content. The combined paper fractions contribute only one quarter of the total chlorine content but about two thirds of the water soluble chlorine content. The "fines", which constitute only 4 mass percent of the total mass (see table 2) contribute 15\% to the total and to the water insoluble chlorine contents and $10 \%$ to the water soluble chlorine content.

\subsection{Comparison of Experimental Results}

The mass percent of the paper in the Baltimore County waste (59\%) and Brooklyn waste (47\%) are grossly comparable (conpare tables 1 and 2 with tables 14 and 15); fewer newspapers and more commercial paper (e.g., office, computer and bank papers) were observed in the Brooklyn paper fraction. The mass percent of the plastic fraction of the Baltimore County waste $(7 \%)$ was two thirds as large as that of the Brooklyn waste (11\%). The mass percent of the hard plastic fraction of the Brooklyn waste (8\%) 
was some two and one half times greater than that from Baltimore County (3\%). The sum of the mass percent of the glass/ceramic and "fines" fractions for Baltimore County (21\%) and Brooklyn (23\%) were comparable. The larger mass percent of the "fines" fraction for the Baltimore County waste (15\%) versus that for Brooklyn (4\%) is probably due to the passage of the Baltimore County waste through the primary shredder prior to our sampling.

Tables 12 and 24 indicate that the total chlorine, water soluble, and water insoluble chlorine are all roughly a factor of two larger for Brooklyn as compared to Baltimore County. From these tables, one sees that the total chlorine content of the Brooklyn waste is larger because of the larger contributions by the Brooklyn plastic fraction, $0.46 \%$ versus $0.14 \%$ for Baltimore County and the Brooklyn, "fines" fraction, $0.13 \%$ versus $0.04 \%$ for Baltimore county. The larger contribution of the Brooklyn wood/vegetable fraction, $0.06 \%$ versus $0.01 \%$ for Baltimore County, is about offset by the smaller contribution of the Brooklyn paper fraction, $0.22 \%$ versus $0.25 \%$ for Baltimore County. The larger contribution to the total chlorine content by the Brooklyn "fines" and wood/vegetable fractions, as well as the larger overall water insoluble chlorine content of the Brooklyn waste, are in part due to the larger food wastes observed in the Brooklyn waste. This could be due to the prohibition of "disposals" in Brooklyn residential areas and also to the fact that the Greenpoint Incinerator receives restaurant waste from Kennedy airport. 


\subsection{Summary and Conclusions}

\section{1 General}

(1) Chlorine in MSW is present in all combustible components.

(2) The major amounts of the chlorine in MSW are contained in the paper and plastic fractions.

(3) The paper fraction contains about one third to half of its chlorine as the water soluble form while the plastic fraction contains most (greater than 90 mass \%) of its chlorine as the water insoluble form.

\subsection{Baltimore County, MD}

The results of the Baltimore County, MD, chlorine content study show the following:

(1) The overall chlorine content for a five day period is $0.52 \%$ (table 11), exclusive of the metal and glass/ceramics fractions, and is $0.45 \%$ of the original dry waste when the metal and glass/ceramics fractions are included; $24 \%$ of the latter chlorine content is water soluble chlorine (table 12).

(2) The paper fraction, which constitutes about $59 \%$ of the waste (table 2), has an average total chlorine content of $0.43 \% ; 35 \%$ of the latter is water soluble chlorine (table 11). The average amount of total chlorine contributed to the original dry waste is $0.25 \%$ (table 12).

(3) The plastic fraction, which constitutes $7 \%$ of the waste (table 2), has an average total chlorine content of $1.29 \%$ for soft (film) plastics, and 2.96\% for hard (rigid) plastics. The water soluble chlorine is less than $10 \%$ of either of the latter values 
(table 11). The combined average amount of total chlorine contributed by the plastic fractions to the original dry waste is $0.14 \%$ (table 12).

(4) The wood and vegetable fraction, which constitues $2 \%$ of the waste (table 2), has an average total chlorine content of $0.35 \%$; about $70 \%$ of this is water soluble chlorine (table 11). The amount of total chlorine contributed by this fraction to the original dry waste is $0.01 \%$ (table 12).

(5) The textile fraction, which constitues $4 \%$ of the original dry waste (table 2), has an average total chlorine content of $0.46 \%$; about $38 \%$ of the latter is water soluble chlorine. The average amount of total chlorine contributed by the textile fraction to the original dry waste is $0.02 \%$ (table 12).

(6) The "fines" or sweepings fraction, which constitutes 15\% of the original dry waste (table 2), has an average total chlorine content of $0.28 \%$; about $23 \%$ of this is water soluble chlorine (table 11). The amount of total chlorine contributed by the "fines" fraction to the original dry waste is $0.04 \%$ (table 12).

(7) If all plastics were removed from the waste stream, the average total chlorine content would decrease from 0.52 to $0.37 \%$ in the composite sample which does not contain metal or glass/ceramic components. The average measured composition of the soft and hard plastic fractions of the composite sample are 5.3 and $3.8 \%$, respectively (table 4). Using average data from table 11, the combined amount of total chlorine contributed by the plastic fraction to the composite samples is $0.18 \%$. Correcting for the 
change in mass fractions gives $(0.52-0.18) /(1-0.091)=0.37 \%$. If the metal and glass/ceramic components were Included, the total chlorine content of the waste stream would change from 0.46 to $0.35 \%$. From table 12 , the plastic fractions contribute $0.14 \%$ to the total chlorine content. Correcting for the change in mass fraction gives $(0.46-0.14) /(1-0.074)=0.35 \%$. The values, $0.37 \%$ or $0.35 \%$ represent a significant presence of chlorine in the waste stream contributed by components other than plastics.

(8) Of the components in Baltimore County, paper contributes most to the total chlorine content. If all of the paper and plastic fractions were removed, the average total chlorine content would decrease from 0.46 to $0.07 \%$. This decrease represents a substantial reduction in total chlorine content, although from a practical standpoint, a difficult reduction to implement.

(9) The MSW sampled in Baltimore County, MD can be classified as a low acid-gas-producing fuel because the sum of the as-received (at the facility) sulfur and chlorine contents does not exceed 0.5 mass $\%(0.10 \% s+0.34 \% \mathrm{Cl}=0.44 \%)$. 


\subsection{Brooklyn, NY}

The results of the Brooklyn, NY, chlorine content study show the

\section{following:}

(1) The overall chlorine content for a five day period is $1.11 \%$ (table 23), exclusive of the metal and glass/ceramics fractions, and is $0.89 \%$ for the original dry waste (table 24) when the metal and glass/ceramic fractions are included; $25 \%$ of the latter chlorine content is water soluble chlorine (table 24).

(2) The unbleached paper fraction, which constitutes about 43\% of the original dry waste (table 15), has an average total chlorine content of $0.49 \%$; $59 \%$ of the latter is water soluble chlorine (table 23). The bleached paper fraction, which constitutes about $5 \%$ of the waste (table 15), has an average total chlorine content of $0.30 \% ; 47 \%$ of the latter is water soluble chlorine (table 23). The combined average amount of total chlorine contributed by the paper fractions to the original dry waste is $0.22 \%$ (table 24 ).

(3) The plastic fraction, which constitutes $11 \%$ of the waste (table 15), has an average total chlorine content of $3.63 \%$ for soft (film) plastics and $4.20 \%$ for hard (rigid) plastics. The water soluble chlorine content is less than $10 \%$ of either of the latter values (table 23). The combined average amount of total chlorine contributed by the plastic fractions to the original dry waste is $0.46 \%$ (table 24) when the metal and glass/ceramics fractions are included. 
(4) The wood and vegetable fraction, which constitutes about $7 \%$ of the original dry waste (table 15), has an average total chlorine content of $0.78 \%$; about $52 \%$ of this is water soluble chlorine (table 23). The average amount of total chlorine contributed by this fraction to the original dry waste is $0.06 \%$ (table 24 ).

(5) The textile fraction, which constitutes about $2 \%$ of the original dry waste (table 15), has an average total chlorine content of $0.74 \%$, about $52 \%$ of the latter is water soluble chlorine (table 23). The average amount of total chlorine contributed by this fraction to the original dry waste is $0.02 \%$ (table 24)

(6) The "fines" or sweepings fraction, which constitutes about $4 \%$ of the orlginal dry waste (table 15), has an average total chlorine content of $2.03 \%$; about $58 \%$ of this is water soluble chlorine (table 23). The average amount of total chlorine contributed by this fraction to the original dry waste is $0.13 \%$ (table 24).

(7) If all plastics were removed from the waste stream, the average total chlorine content would decrease from 1.11 to $0.55 \%$ in the composite sample which does not contain metal and glass/ceramic components. The average measured compositions of the soft and hard plastic fractions of the composite sample are 4.4 and $11.6 \%$, respectively (table 16 ). Using average data from table 23, the combined amount of total chlorine contributed by the plastic fraction to the composite sample is $0.65 \%$. Correcting for the change in mass fraction, one has $(1.11-0.65) /(1-0.16)=$ $0.55 \%$. If the metal and glass/ceramic components were included, the total chlorine content would change from 0.89 to 
$0.48 \%$. From table 24, the plastios fractions contribute $0.45 \%$

to the total chlorine content. Correcting for the change in mass fractions (see table 2) gives $(0.89-0.46) /(1-.113)=.48 \%$. The values $0.54 \%$ or $0.50 \%$ represent a significant presence of chlorine in the waste stream contributed by components other than plastics. Of these, most of the total chlorine content is contributed by the plastics.

(8) If all of the paper and plastic fractions were removed, the average total-chlorine content would decrease from 0.89 to $0.21 \%$. This decrease represents a substantial reduction in total-chlorine content, although from a practical standpoint, a difficult reduction to implement.

(9) The MSW sampled in Brooklyn, NY cannot be classified as a low acid-gas-producing fuel because the sum of the as-received (at the facility) sulfur and chlorine contents does exceed 0.5 mass\% $(0.12 \% s+0.74 \% \mathrm{Cl}=0.86 \%)$. 
5. References

[1] Olie, K., Vermeulen, P.L., and Hutzinger, O., Chemosphere $\underline{6}, 455$ (1977).

[2] Buser, H., Bosshardt, H., and Rappe, C., Chemosphere 7, 165 (1978).

[3] Eiceman, G.A., Clement, R.E., and Karasek, F. W., Anal. Chem. 51, $2343(1979)$

[4] Lustenhauwer, J.A., Olie, K.I., and Hutzinger, 0., Chemosphere $\underline{9}, 501$ (1980).

[5] Cavallaro, A., Bandi, G., Invernizzi, G., Luciana, L., Mongini, E., and Gorni, A., Chemosphere 9 , 611 (1980).

[6] Karasek, F.W., Clement, R.E., and Viau, A.C., J. Chromatography 239, $173(1982)$.

[7] Tiernan, T.0., Taylor, M.L., Garrett, J.H., Van Ness, G.F., Solch, J.C., Dies, D.A., and Wagel, D.J., Chemosphere 12, 595 (1983).

[8] Olie, K., Berg, M.v.d., and Hutzinger, 0., Chemosphere 12, 627 (1983).

[9] Liberti, A., Goretti, G., and Russo, M.V., Chemosphere 12, 661 (1983).

[10] Hollander, H.I., Eller, V.I., Stephenson, J.W., and Kieffer, J.K., "A Comprehensive Municipal Refuse Characterization Program," Ninth ASME National Waste Processing Conference, Washington, D.C., May 11$14,(1980)$ 
[11] Churney, K.L., Domalski, E.S., Ledford, Jr., A.E., Colbert, J.C., Bruce, S.S., Buckley, T.J., Paule, R.C., and Reilly, M.L. "Assessing the Credibility of the Calorific Value of Municipal Solid Waste", NBSIR 84-2825(DOE), U.S. National Bureau of Standards, Gaithersburg, MD, February 1984.

[12] Mandel, J., and Paule, R.C., "Interlaboratory Evaluation of a Material with Unequal Numbers of Replicates," Anal. Chem. 42, 1194 (1970) and Correction, Anal. Chem. 43, 1287 (1971).

[13] Mandel, J. "Repeatability and Reproducibility," Materials Research and Standards, 11 (No. 8), 8 (1971), American Society for Testing Materials, 1916 Race Street, Philadelphia, PA.

[14] ASTM Standard Method E456-83a Standard Terminology for Statistical Methods, approved April 6, 1983.

[15] Dixon, W.J., and Massey, F.J., Jr., "Introduction to Statistical Analysis," McGraw-Hill Book Co., New York, 1951).

[16] Kendall, M.G., and Buckland, W.R., "A Dictionary of Statistical Terms," Third Edition, Hafner Publications New York, 1971). 


\subsection{Acknowledgments}

We acknowledge the cooperation and assistance provided by the Baltimore County Resource Recovery Facility in Cockeysville, MD and the Greenpoint Incinerator Facility in Brooklyn, NY for allowing us to sample their municipal solid waste.

Primary financial support for this research program has come from the Office of Renewable Technology, Biofuels and Municipal Waste Technology Division, U.S. Department of Energy, Washington, D.C. Supplemental financial support has also been provided by the City of New York, Department of Sanitation, Office of Resource Recovery and Waste Disposal Planning, New York, NY. 


\section{Appendix Definitions of Statistical Parameters}

The definitions given below have been taken from references $[14,15$, and 16]. In some cases, minor modifications have been made to definitions so that there might be a closer relatability to the subject matter of this report.

Accuracy The closeness of agreement between an observed value and an accepted reference value.

Average The arithmetic mean or central value of a population; the sum of all observed values divided by the number of observed values. If there are $n$ observed values: $\mathrm{X}=\left(\mathrm{x}_{1}+\mathrm{x}_{2}+\mathrm{x}_{3}\right.$. $\left.+x_{n}\right) / n$

Coefficient of Variation

A measure of relative precision calculated as the standard deviation divided by the average. $(s t d \cdot d e v) /$.

Component of Variance

A part of the total variance identified with a specified source of variablity, i.e., within-day variability or between-day variability.

Mean A synonym for average.

Precision The closeness of agreement between randomly selected individual measurements or test results.

Standard Deviation A measure of the dispersion of observed values or results expressed as the positive square root of the variance.

$$
\left[\Sigma\left(x_{i}-\bar{x}\right)^{2} /(n-1)\right]^{1 / 2}
$$

Standard Deviation of the Mean

A measure of the dispersion of observed means expressed as the positive square root of the variance

$$
\left[\Sigma\left(X_{1}-\bar{x}\right)^{2} /(n(n-1))\right]^{1 / 2}
$$

Variance Square of the standard deviation.

$$
\Sigma\left(X_{i}-\bar{X}\right)^{2} /(n-1)
$$



Table 1. Average Composition of Municipal Solid Waste obtained from the Baltimore County Resource Recovery Facility, Cockeysville, MD, during January, 1983.

Component

1) Total Moisture

2) Paper

$$
\begin{aligned}
& \text { Plastics, soft } \\
& \text { Plastics, hard }
\end{aligned}
$$

3) Plastics, total

4) Wood/Vegetable

5) Textiles

6) Metal

7) Glass/Ceramics

8) "Fines"
(Mass \%, As-Recelved at the Facility)

25.8

43.5

\section{5}

2.0

5.5

1.3

3.2

5.3

4.3

11.1 
Table 2. Composition of Municipal Sol1d Waste Obtained 10, 11, 12, 19, 21 January 1983 from the Baltimore County Resource Recovery

Facility, Cockeysville, MD.

Day

1

2

34

5

Average

(Mass\%, As-Received at the Facility)

1) Total

Moisture

25.9

22.4

34.5

23.5

20.9

25.8

(Mass \%, Dry Basis)

2) Paper

$50.9 \quad 56.9$

61.5

56.6

67.6

58.7

Plastics,

4.0

2.2

3.0

9.2

5.0

4.7

soft

Plastics,

3.0

3.0

1.9

3.6

2.1

2.7

hard

3) Plastics, total

7.0

5.2

4.9

12.8

7.1

7.4

4) Wood/

vegetable

2.9

2.1

1.0

0.4

1.9

1.7

5) Textiles

3.6

0.8

0.5

11.7

5.1

4.3

6) Metal

10.9

10.0

7.9

1.1

5.4

7.1

7) Glass/

Ceramics

5.8

10.9

5.8

2.7

3.8

5.8

8) "Fines"

$18.9 \quad 14.1$

18.4

14.7

9.1

15.0

9) Combustible content

64.4

65.0

67.9

81.5

81.7

72.1

10) Noncombustible content

35.6

35.0

32.1

18.5

18.3

27.9 
Table 3. Processing of Waste Components

\begin{tabular}{|c|c|c|c|}
\hline Component & $\frac{\text { Initial }}{\text { Processing }}$ & $\frac{\text { Final Particle }}{\text { Size Reduction }}$ & Blending \\
\hline Paper & --- & $\begin{array}{l}\text { Hammer Mill, } \\
3 \mathrm{~mm} \text { sieve }\end{array}$ & $\begin{array}{l}\text { Hand mix in } \\
\text { storage bags }\end{array}$ \\
\hline Plastic, soft & $\begin{array}{l}\text { Remove metals, } \\
\text { shear to } 20-25 \mathrm{~mm} \\
\text { size }\end{array}$ & $\begin{array}{l}\text { SR-3 Mill, } \\
2 \mathrm{~mm} \text { sieve } \\
\text { dry ice }\end{array}$ & $\begin{array}{l}\text { Vee blend with } \\
\text { intensifier }\end{array}$ \\
\hline Plastic, hard & $\begin{array}{l}\text { Hammer Mill } \\
12 \mathrm{~mm} \text { sieve }\end{array}$ & do & $\begin{array}{l}\text { Vee blend without } \\
\text { intensifier }\end{array}$ \\
\hline Wood/Vegetable & $\begin{array}{l}\text { Remove metals, } \\
\text { shear to } 20-25 \mathrm{~mm} \\
\text { size }\end{array}$ & $\begin{array}{l}\text { Wiley Mill, } \\
2 \mathrm{~mm} \text { sieve } \\
\text { dry ice }\end{array}$ & do \\
\hline Textiles & do & do & $\begin{array}{l}\text { Vee blend with } \\
\text { intensifier }\end{array}$ \\
\hline "Fines" & $\begin{array}{l}\text { Remove magnetic } \\
\text { metals with } \\
\text { magnet }\end{array}$ & $\begin{array}{l}\mathrm{ZM}-1 \text { Mill, } \\
2 \mathrm{~mm} \text { sieve }\end{array}$ & $\begin{array}{l}\text { Vee blend without } \\
\text { intensifier }\end{array}$ \\
\hline
\end{tabular}




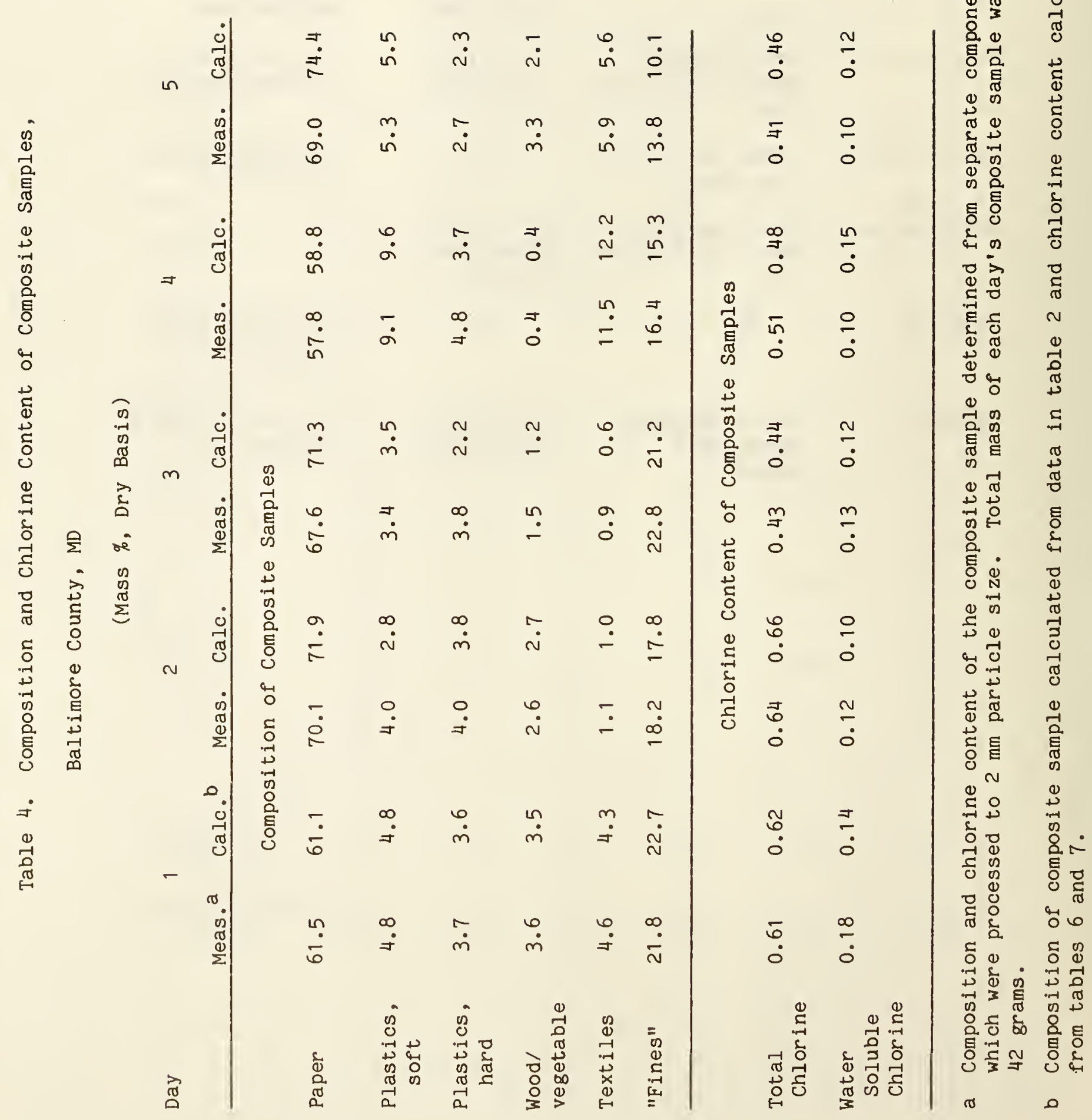


Table 5. Residual Moisture Content,

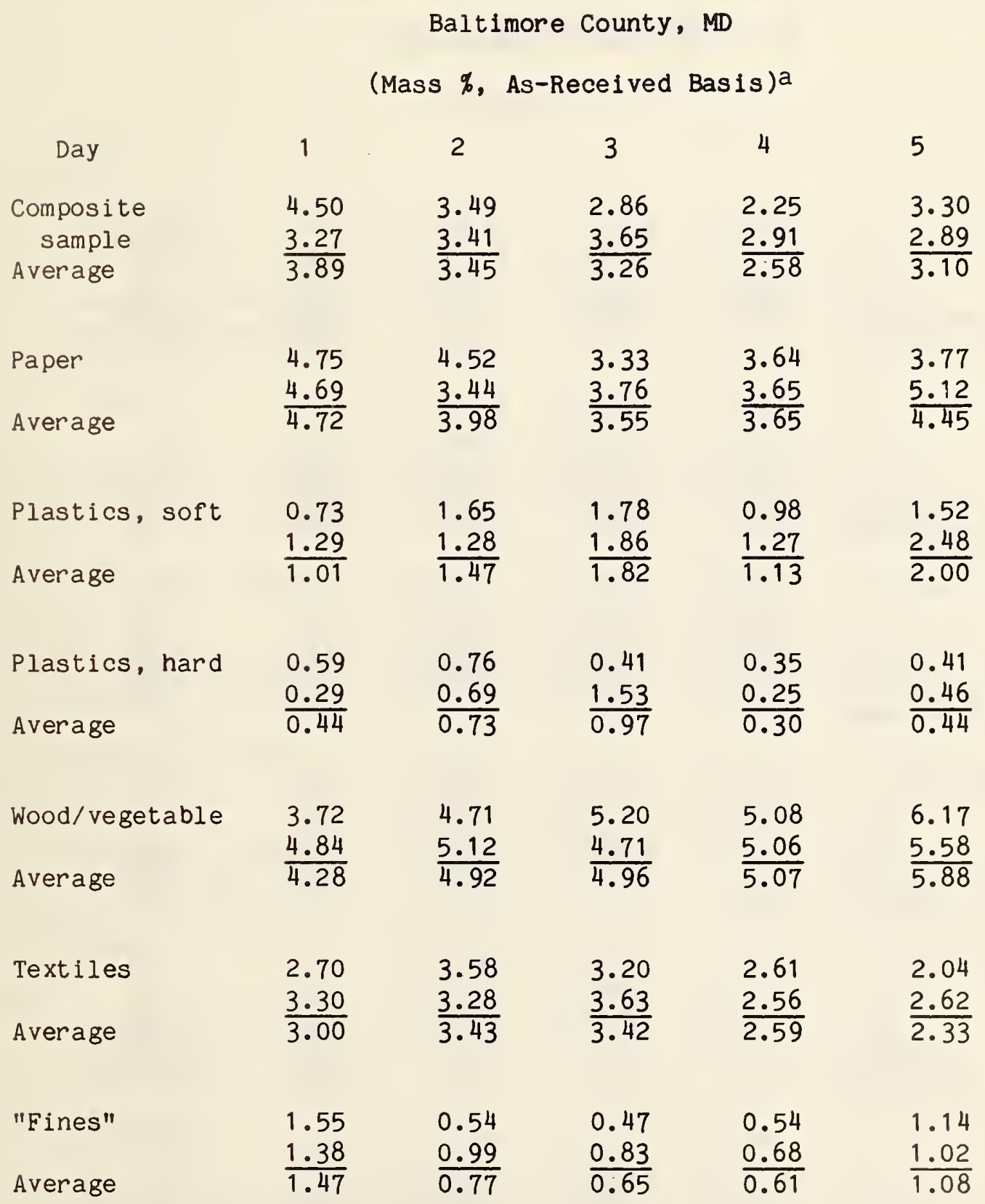

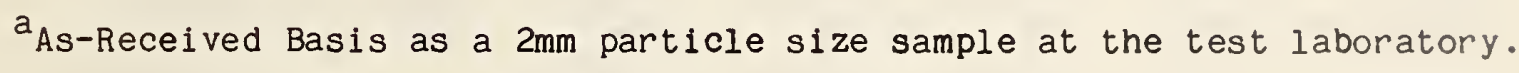




\section{Table 6. Total Chlorine Content, \\ Balt1more County, MD}

(Mass \%)

\begin{tabular}{|c|c|c|c|c|c|}
\hline Day & 1. & 2 & 3 & 4 & 5 \\
\hline Composite & 0.51 & 0.51 & 0.39 & 0.48 & 0.45 \\
\hline Sample & $\begin{array}{l}0.70 \\
0.56\end{array}$ & $\begin{array}{l}0.84 \\
0.50\end{array}$ & $\begin{array}{l}0.39 \\
0.46\end{array}$ & $\begin{array}{l}0.42 \\
0.60\end{array}$ & $\begin{array}{l}0.41 \\
0.34\end{array}$ \\
\hline Average, As-Rec'da & 0.59 & 0.62 & 0.41 & 0.50 & 0.40 \\
\hline Average, Dry-Basis & 0.61 & 0.64 & 0.43 & 0.51 & 0.41 \\
\hline \multirow[t]{3}{*}{ Paper } & 0.41 & 0.36 & 0.40 & 0.39 & 0.31 \\
\hline & 0.50 & 0.43 & 0.42 & 0.40 & 0.34 \\
\hline & 0.59 & 0.35 & 0.40 & 0.50 & 0.39 \\
\hline Average, As-Rec'd & 0.50 & 0.38 & 0.41 & 0.43 & 0.35 \\
\hline Average, Dry-Basis & 0.52 & 0.40 & 0.42 & 0.45 & 0.37 \\
\hline \multirow[t]{3}{*}{ Plastics, soft } & 1.43 & 1.18 & 1.41 & 0.68 & 1.64 \\
\hline & 1.28 & 1.40 & 1.12 & 0.76 & 1.68 \\
\hline & 1.40 & 1.40 & 1.22 & 0.80 & 1.60 \\
\hline Average, As-Rec'd & $\overline{1.37}$ & $\overline{1.33}$ & $\overline{1.25}$ & $\overline{0.75}$ & 1.64 \\
\hline Average, Dry-Basis & 1.38 & 1.35 & 1.27 & 0.76 & 1.67 \\
\hline \multirow[t]{3}{*}{ Plastics, hard } & 2.45 & 6.87 & 1.78 & 1.30 & 2.51 \\
\hline & 3.79 & $7 \cdot 10$ & 1.23 & 1.23 & 2.25 \\
\hline & 2.96 & 6.53 & 1.31 & 0.78 & 2.12 \\
\hline Average, As-Rec'd & $\overline{3.07}$ & 6.83 & $\overline{1.44}$ & $\overline{1.10}$ & $\overline{2.29}$ \\
\hline Average, Dry-Basis & 3.08 & 6.88 & 1.45 & 1.11 & 2.30 \\
\hline \multirow[t]{3}{*}{ Wood/vegetable } & 0.17 & 0.08 & 0.13 & 0.50 & 0.54 \\
\hline & 0.23 & 0.42 & 0.21 & 0.53 & 0.57 \\
\hline & 0.19 & 0.41 & 0.07 & 0.48 & 0.46 \\
\hline Average, As-Rec'd & $\overline{0.20}$ & $\overline{0.30}$ & $\overline{0.14}$ & $\overline{0.50}$ & $\overline{0.52}$ \\
\hline Average, Dry-Basis & 0.21 & 0.32 & 0.14 & 0.53 & 0.56 \\
\hline \multirow[t]{3}{*}{ Textiles } & 1.06 & 0.31 & 0.32 & 0.37 & 0.20 \\
\hline & 1.09 & 0.22 & 0.25 & 0.25 & 0.18 \\
\hline & 1.37 & 0.24 & 0.30 & 0.30 & 0.17 \\
\hline Average, As-Rec'd & $\overline{1.17}$ & $\overline{0.26}$ & $\overline{0.29}$ & $\overline{0.31}$ & $\overline{0.18}$ \\
\hline Average, Dry-Basis & 1.21 & 0.27 & 0.30 & 0.32 & 0.19 \\
\hline \multirow[t]{3}{*}{ "Fines" } & 0.27 & 0.22 & 0.17 & 0.36 & 0.39 \\
\hline & 0.25 & 0.19 & 0.24 & 0.37 & 0.32 \\
\hline & 0.29 & 0.19 & 0.32 & 0.34 & 0.26 \\
\hline Average, As-Rec'd & $\overline{0.27}$ & $\overline{0.20}$ & $\overline{0.24}$ & $\overline{0.36}$ & $\overline{0.32}$ \\
\hline Average, Dry-Basis & 0.27 & 0.20 & 0.25 & 0.36 & 0.33 \\
\hline
\end{tabular}

A Average, As-Recelved as a $2 \mathrm{~mm}$ particle size sample at the test laboratory. 
Table 7. Water Soluble Chlorine Content, Balt1more County, MD

(Mass \%)

\begin{tabular}{|c|c|c|c|c|c|}
\hline Day & 1 & 2 & 3 & 4 & 5 \\
\hline Composite & 0.13 & 0.11 & 0.13 & 0.13 & 0.04 \\
\hline Sample & 0.22 & 0.12 & 0.13 & 0.01 & 0.12 \\
\hline & 0.17 & 0.11 & 0.12 & 0.15 & 0.13 \\
\hline Average, As-Rec' $d^{a}$ & $\overline{0.17}$ & $\overline{0.11}$ & $\overline{0.13}$ & $\overline{0.10}$ & $\overline{0.10}$ \\
\hline Average, Dry Basis & 0.18 & 0.12 & 0.13 & 0.10 & 0.10 \\
\hline Paper & 0.19 & 0.14 & 0.15 & 0.17 & 0.11 \\
\hline & 0.17 & 0.02 & 0.16 & 0.19 & 0.13 \\
\hline & 0.16 & 0.16 & 0.16 & 0.18 & 0.11 \\
\hline Average, As-Rec'da & $\overline{0.17}$ & $\overline{0.11}$ & $\overline{0.16}$ & $\overline{0.18}$ & $\overline{0.12}$ \\
\hline Average, Dry Basis & 0.18 & 0.11 & 0.17 & 0.19 & 0.12 \\
\hline Plastics, soft & $0.08=$ & 0.07 & 0.07 & 0.11 & 0.09 \\
\hline & 0.09 & 0.08 & 0.09 & 0.10 & 0.10 \\
\hline & 0.09 & 0.06 & 0.06 & 0.10 & 0.11 \\
\hline Average, As-Rec' $d^{a}$ & $\overline{0.09}$ & $\overline{0.07}$ & $\overline{0.07}$ & $\overline{0.10}$ & $\overline{0.10}$ \\
\hline Average, Dry Basis & 0.09 & 0.07 & 0.07 & 0.10 & 0.10 \\
\hline Plastics, hard & 0.01 & 0.00 & 0.01 & 0.01 & 0.01 \\
\hline & 0.00 & 0.01 & 0.01 & 0.01 & 0.01 \\
\hline & 0.01 & 0.00 & 0.00 & 0.01 & 0.01 \\
\hline Average, As-Rec' $d^{a}$ & $\overline{0.01}$ & 0.00 & $\overline{0.01}$ & $\overline{0.01}$ & $\overline{0.01}$ \\
\hline Average, Dry Basis & 0.01 & 0.00 & 0.01 & 0.01 & 0.01 \\
\hline Wood/vegetable & 0.12 & 0.16 & 0.16 & 0.32 & 0.26 \\
\hline & 0.09 & 0.20 & 0.13 & 0.40 & 0.25 \\
\hline & 0.10 & 0.30 & 0.14 & 0.43 & 0.27 \\
\hline Average, As-Rec' da & 0.10 & 0.22 & 0.14 & 0.38 & 0.26 \\
\hline Average, Dry Basis & 0.11 & 0.23 & 0.15 & 0.40 & 0.28 \\
\hline Textiles & 0.16 & 0.11 & 0.12 & 0.15 & 0.10 \\
\hline & 0.16 & 0.12 & 0.13 & 0.14 & 0.10 \\
\hline & 0.14 & 0.12 & 0.11 & 0.15 & 0.07 \\
\hline Average, As-Rec' $d^{a}$ & $\overline{0.15}$ & $\overline{0.12}$ & $\overline{0.12}$ & 0.15 & 0.09 \\
\hline Average, Dry Basis & 0.16 & 0.12 & 0.12 & 0.15 & 0.09 \\
\hline "Fines" & 0.08 & 0.05 & 0.04 & 0.06 & 0.10 \\
\hline & 0.09 & 0.06 & 0.04 & 0.06 & 0.10 \\
\hline & 0.04 & 0.05 & 0.04 & 0.06 & 0.09 \\
\hline Average, As-Rec' $d^{a}$ & $\overline{0.07}$ & 0.05 & 0.04 & 0.06 & 0.10 \\
\hline Average, Dry Basis & 0.07 & 0.05 & 0.04 & 0.06 & 0.10 \\
\hline
\end{tabular}

average, As-Received as a $2 \mathrm{~mm}$ particle size sample at the test laboratory. 
Table 8. Sulfur Content of Composite Samples,

Baltimore County, MD

(Mass \%)

\begin{tabular}{lcccccc} 
Day & 1 & 2 & 3 & 4 & 5 & Average \\
Sample 1 & 0.22 & 0.05 & 0.10 & 0.06 & 0.17 & \\
Sample 2 & 0.17 & 0.14 & 0.06 & 0.14 & 0.22 & \\
$\begin{array}{l}\text { Sample 3 } \\
\text { Average, }\end{array}$ & 0.17 & 0.12 & 0.11 & 0.06 & 0.14 & \\
\hline $\begin{array}{c}\text { As-Rec'd } \\
\text { Average, } \\
\text { Dry Basis }\end{array}$ & 0.19 & 0.10 & 0.09 & 0.09 & 0.18 & 0.13 \\
& 0.19 & 0.11 & 0.09 & 0.09 & 0.18 & 0.13
\end{tabular}

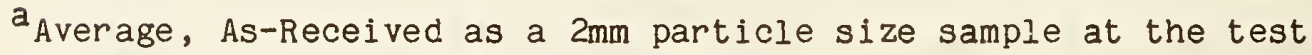
laboratory . 


\section{Table 9. Variability of Total Chlorine Content, Baltimore County, MD}

\begin{tabular}{|c|c|c|c|c|}
\hline & Average & $\begin{array}{l}\text { Std.a } \\
\text { Dev. }\end{array}$ & \% Within-Day & Between-Day \\
\hline & (Mass \%, & Dry Basis) & $(\% c \cdot V \cdot b)$ & $(\%$ c.V. $)$ \\
\hline $\begin{array}{c}\text { Composite } \\
\text { Sample }\end{array}$ & 0.52 & .05 & 21 & 16 \\
\hline Paper & 0.43 & .03 & 13 & 12 \\
\hline Plastics, soft & 1.29 & .15 & $8^{\circ}$ & 25 \\
\hline Plastics, hard & 2.96 & 1.04 & 13 & 78 \\
\hline Wood/vegetable & 0.35 & .08 & 28 & 51 \\
\hline Textiles & 0.46 & .19 & 19 & 92 \\
\hline "Fines" & 0.28 & .03 & 16 & 21 \\
\hline
\end{tabular}


Table 10. Variability of Water Soluble Chlorine Content, Baltimore county, MD

\begin{tabular}{|c|c|c|c|c|}
\hline & Average, $\%$ & $\begin{array}{l}\text { Std.a } \\
\text { Dev. }\end{array}$ & Within-Day & Between-Day \\
\hline & (Mass \%, Dry & Basis) & $(\%$ C.V. $)$ & $(\%$ C.V. $)$ \\
\hline $\begin{array}{r}\text { Composite } \\
\text { sample }\end{array}$ & 0.13 & .01 & 35 & 16 \\
\hline Paper & 0.15 & .02 & 23 & 20 \\
\hline Plastics, soft & 0.09 & .01 & 11 & 16 \\
\hline Plastics, hard & 0.01 & .002 & 50 & 35 \\
\hline Wood/vegetable & 0.23 & .05 & 18 & 48 \\
\hline Textiles & 0.13 & .01 & 8 & 21 \\
\hline "Fines" & 0.06 & .01 & 20 & 35 \\
\hline
\end{tabular}




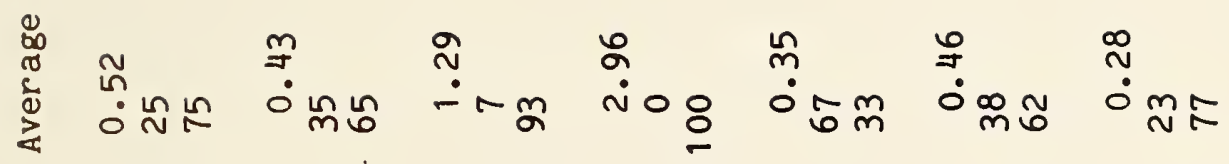

물

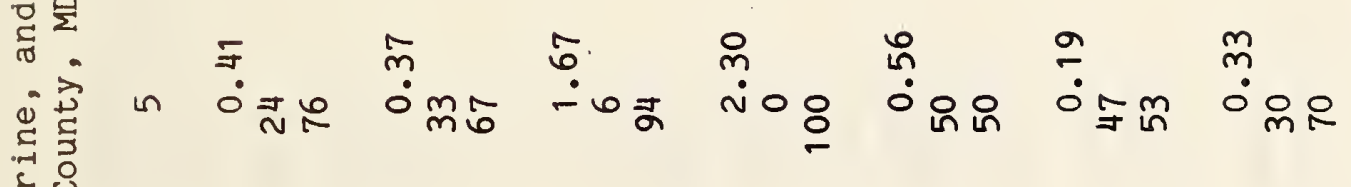

공

(1)

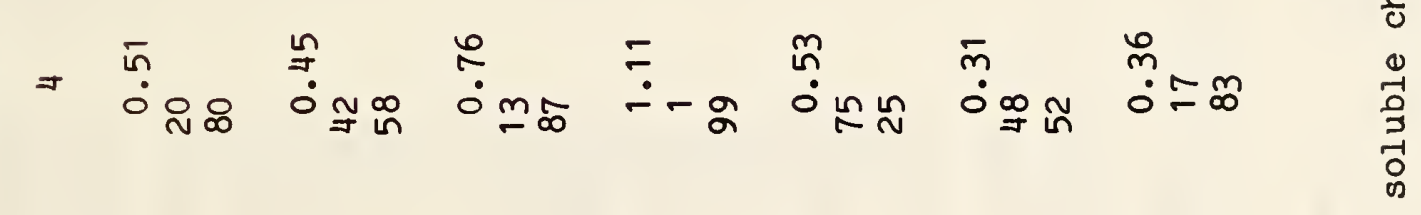

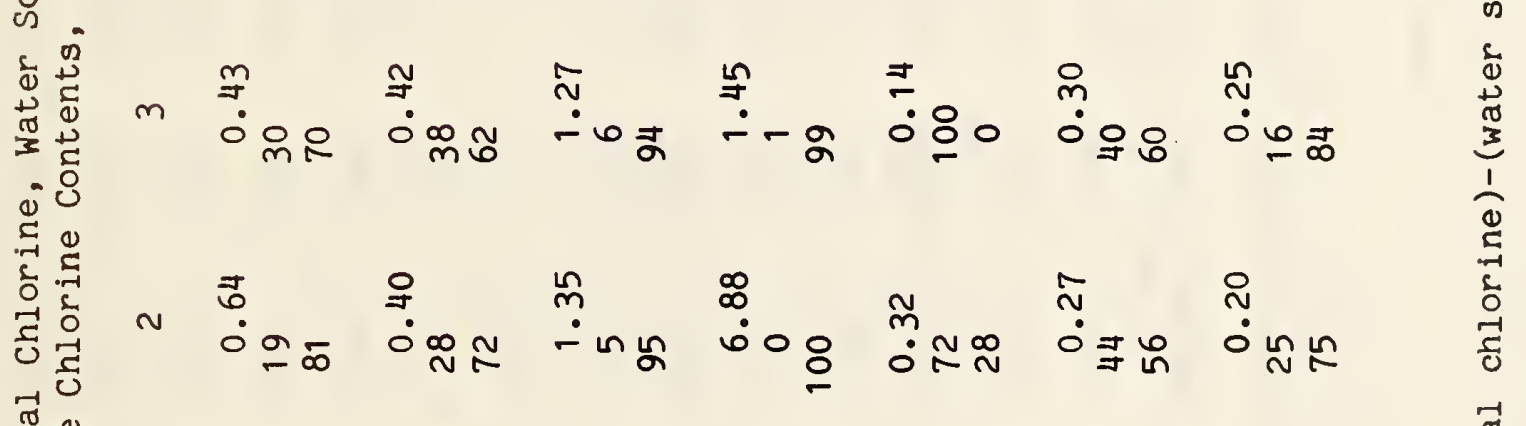

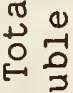

容 -

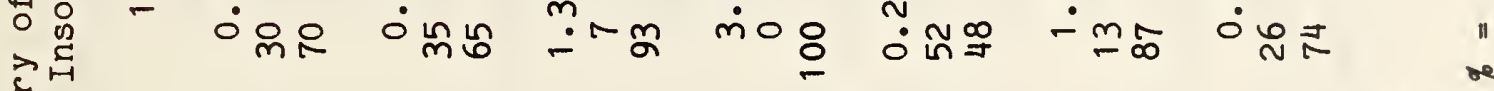

क

$\begin{array}{llllllll} & \\ 0\end{array}$




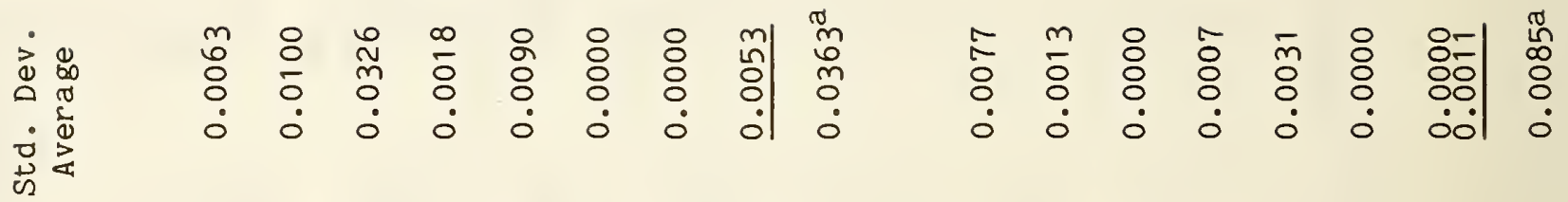

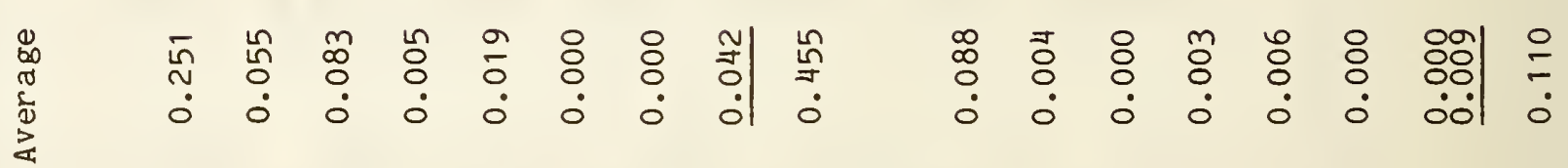

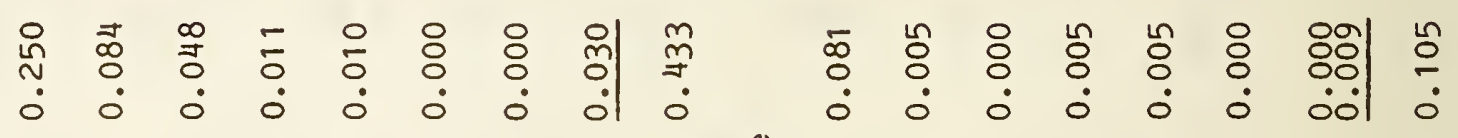
aे

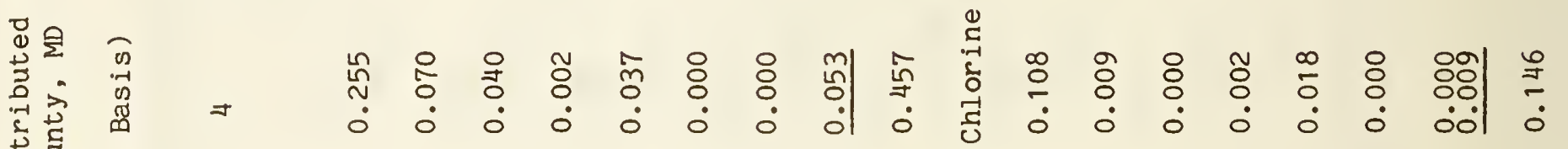

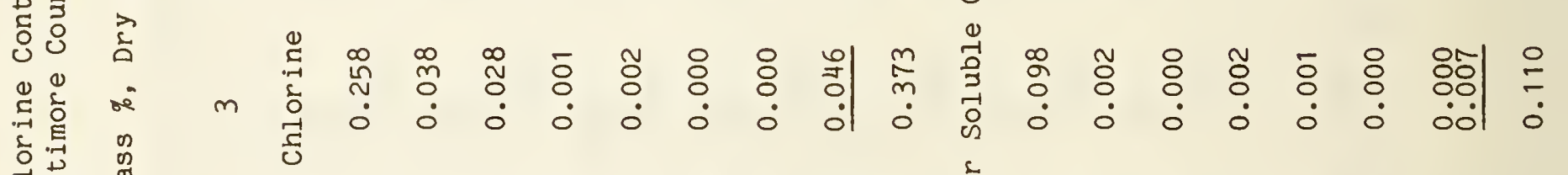

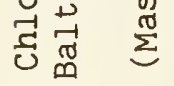
웅

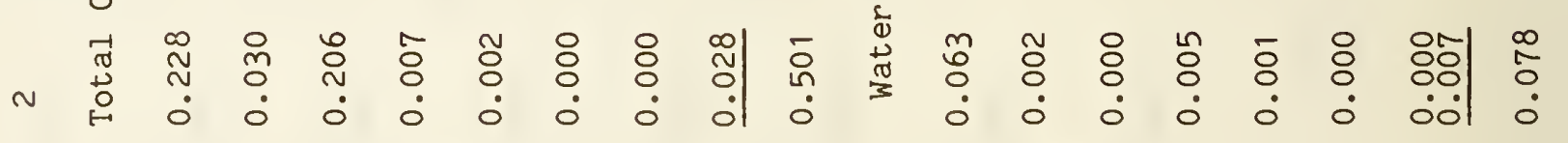

善

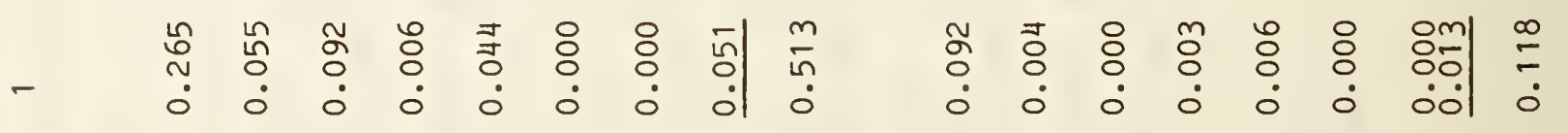

要

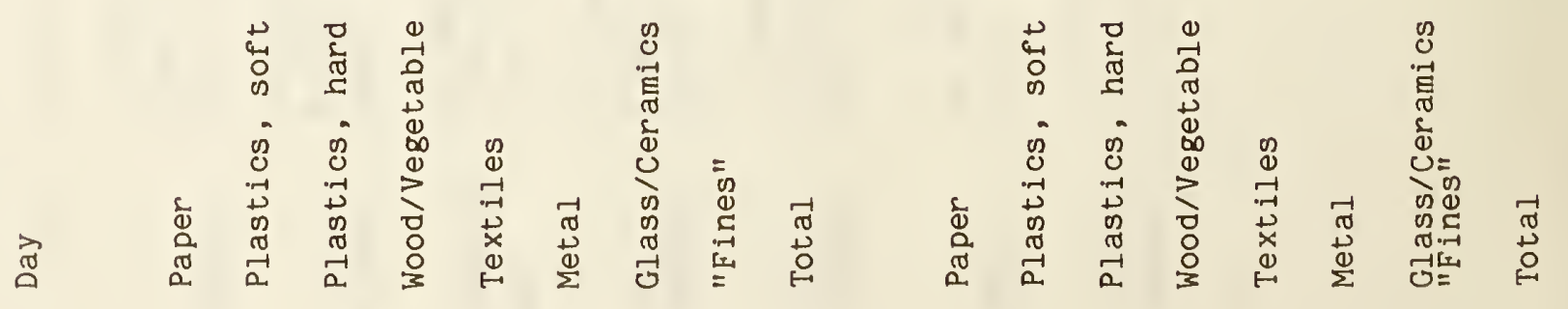




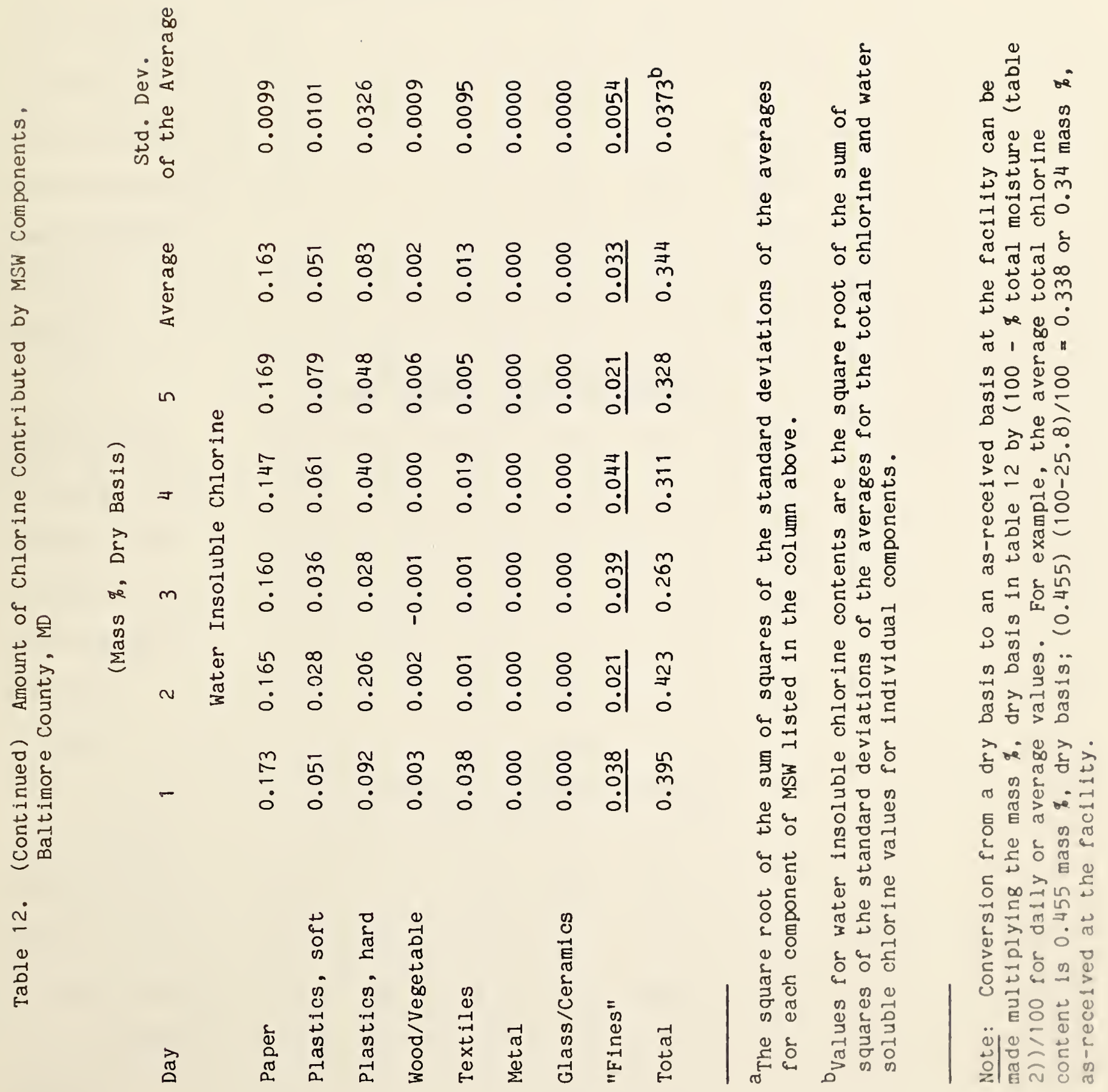



Table 13. Calculated Percent of Chlorine Contributed by Components of Baltimore County MSW to Chlorine Content

(Percent of sum of components for each day, dry initial composition)

\begin{tabular}{|c|c|c|c|c|c|c|}
\hline \multirow[t]{2}{*}{ Day } & 1 & 2 & 3 & 4 & 5 & Average \\
\hline & \multicolumn{4}{|c|}{ Total Chlorine Content } & & \\
\hline Paper, total & 51 & 46 & 69 & 56 & 58 & 56 \\
\hline Plastics, soft & 11 & 6 & 10 & 15 & 19 & 12 \\
\hline Plastics, hard & 18 & 41 & 8 & 9 & 11 & 18 \\
\hline Plastics, total & 29 & 47 & 18 & 24 & 30 & 30 \\
\hline Wood/Vegetable & 1 & 1 & 0 & 0 & 3 & 1 \\
\hline Textiles & 9 & 0 & 1 & 8 & 2 & 4 \\
\hline \multirow[t]{2}{*}{ "Fines" } & 10 & 6 & 12 & 12 & 7 & 9 \\
\hline & \multicolumn{6}{|c|}{ Water Soluble Chlorine Content } \\
\hline Paper, total & 78 & 81 & 89 & 74 & 77 & 80 \\
\hline Plastics, soft & 3 & 3 & 2 & 6 & 5 & 4 \\
\hline Plastics, hard & 0 & 0 & 0 & 0 & 0 & 0 \\
\hline Plastics, total & 3 & 3 & 2 & 6 & 5 & 4 \\
\hline Wood/Vegetable & 3 & 6 & 2 & 1 & 5 & 3 \\
\hline Textiles & 5 & 1 & 1 & 12 & 5 & 5 \\
\hline "Fines" & 11 & 9 & 6 & 6 & 8 & 8 \\
\hline
\end{tabular}

Water Insoluble Chlorine Content

$\begin{array}{lrrrrrr}\text { Paper, total } & 43 & 39 & 61 & 47 & 51 & 47 \\ \text { Plastics, soft } & 13 & 7 & 14 & 20 & 24 & 15 \\ \text { Plastics, hard } & 23 & 49 & 10 & 13 & 15 & 24 \\ \text { Plastics, total } & 36 & 56 & 24 & 33 & 39 & 39 \\ \text { Wood/Vegetable } & 1 & 0 & 0 & 0 & 2 & 0 \\ \text { Textiles } & 10 & 0 & 0 & 6 & 2 & 4 \\ \text { "Fines" } & 10 & 5 & 15 & 14 & 6 & 10\end{array}$


Table 14. Average Composition of Municipal Solid Waste Obtained from the Greenpoint Incinerator Facility, Brooklyn, NY, during January 1984 (Mass \%, As-Received at the Facility)

Component

1) Total Moisture

$$
\text { Paper, unbleached }
$$

Paper, bleached

2) Paper, total

Plastics, soft

Plastics, hard

3) Plastics, total

4) Wood/Vegetable

5) Textiles

6) Metal

7) Glass/Ceramics

8) "Fines"
(Mass \%, As-Received at the Facility)

16.0

35.7

3.9

39.6

2.9

6.6

9.5

6.1

1.9

8.1

15.5

3.3 
Table 15. Composition of Municipal Solid Waste Obtained 30 January 1984 3 February 1984 from the Greenpoint Incinerator, Brooklyn, NY

Day

$$
1
$$

2

34

5

Average

(Mass \%, As-Received at the Facility)

$\begin{array}{lcccccc}\text { 1) Total Moisture } & 16.6 & 18.4 & 15.3 & 15.8 & 13.9 & 16.0 \\ \begin{array}{l}\text { Paper, } \\ \text { unbleached }\end{array} & 46.0 & 43.7 & 44.3 & 40.7 & 37.7 & 42.5 \\ \begin{array}{l}\text { Paper, } \\ \text { bleached }\end{array} & 4.7 & 3.0 & 6.2 & 5.0 & 4.3 & 4.6\end{array}$
2) Paper, total
$50.7 \quad 46.7 \quad 50.5$
45.7
42.0
47.1
Plastics, soft
$2.3 \quad 4.6 \quad 3.4$
5.1
1.5
3.4
Plastics, hard
$\begin{array}{lll}6.9 & 7.2 \quad 5.9\end{array}$
8.9
10.6
$7 \cdot 9$

3) Plastics, total

$9.2 \quad 11.8$

$9.3 \quad 14.0$

12.1

11.3

4) Wood/Vegetable

$5.9 \quad 7.0$

8.1

8.1

6.9

7.2

5) Textiles

$\begin{array}{lll}3.0 & 1.7 & 2.1\end{array}$

3.1

1.8

2.3

6) Metals

$\begin{array}{lll}7.4 & 11.3 \quad 11.9\end{array}$

6.9

10.9

9.7

7) Glass/Ceramics

$15 \cdot 3$

$18.7 \quad 15.9$

$17 \cdot 3$

25.4

18.5

8) "Fines"

$\begin{array}{lll}8.5 & 2.8 & 2.2\end{array}$

4.9

0.9

3.9

9) Combustible content

$\begin{array}{llll}68.8 & 67.2 & 70.0 & 70.9\end{array}$

62.8

67.9

10) Noncombustible content

$31.2 \quad 32.8 \quad 30.0$

29.1

37.2

32.1 
D)

in

0
0
0
0
0
0
0
0
0

$\sum_{\substack{\infty \\ \tilde{0}}}^{\dot{0}}$

2 in

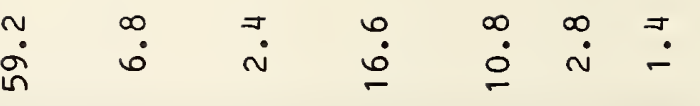

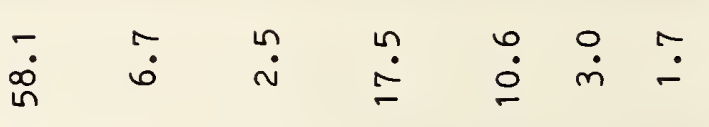

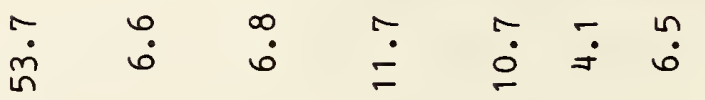

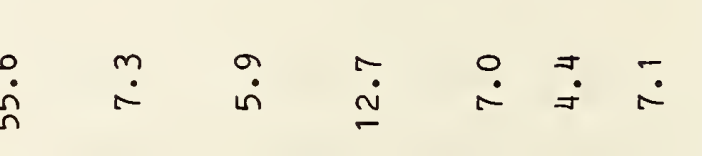

空

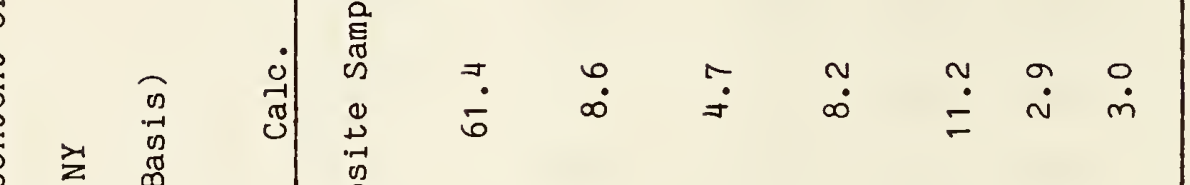

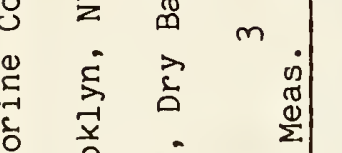

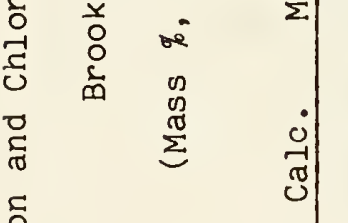

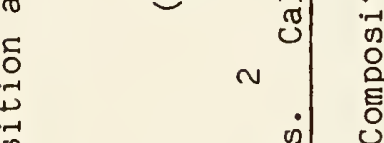

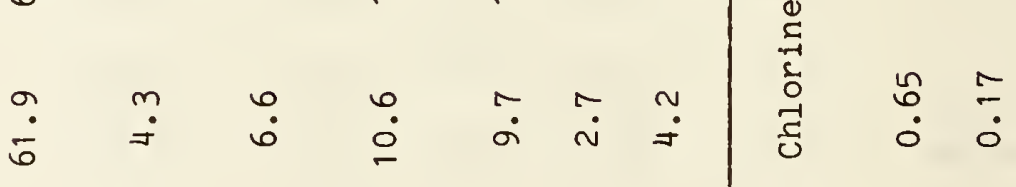

0
0
0
0
0
7
0
0
-
0
0
0
0
2
2

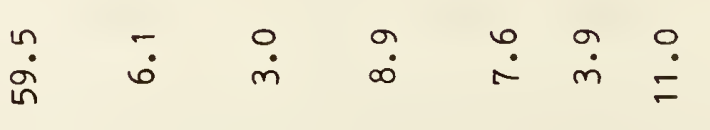

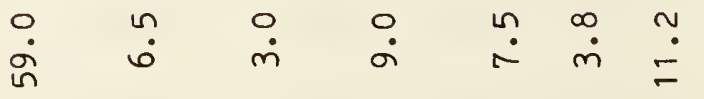

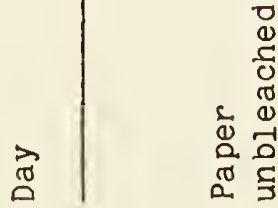

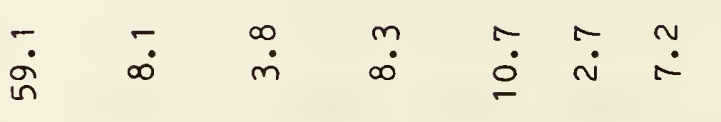

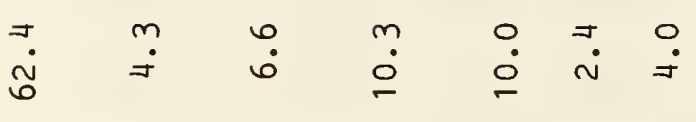

$\stackrel{\text { ํ. }}{-} \stackrel{\vec{m}}{0}$

$\stackrel{n}{\dddot{m}} \stackrel{\mathfrak{0}}{\stackrel{0}{0}}$

$\begin{array}{ll}\infty & 0 \\ 0 & 0\end{array}$

$\underset{0}{m} \tilde{0}$

$\stackrel{\circ}{\circ} \stackrel{\div}{0}$

$\begin{array}{ll}\cong & \Xi \\ 0 & 0\end{array}$

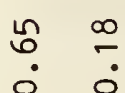

$\begin{array}{ll}\bar{m} & \infty \\ \dot{\sim} & 0\end{array}$

$\begin{array}{ll}\circ & \text { वे } \\ \dot{0} & 0\end{array}$

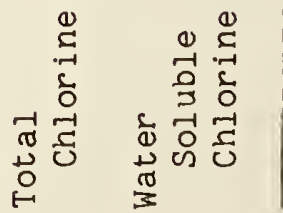

్ㅗㄴ

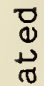

욱

0
0
0
0
0
0
0
0
0

(1)

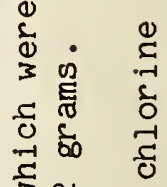

क व

造

咅 $\frac{\pi}{3}$

०

苛

है

बू

क

ㅌํㅇ 응

\&

हิ

000

$\stackrel{\infty}{ \pm} \infty$

है

岂

(2)

$\stackrel{0}{2}$

拿

की

ब

$\stackrel{\square}{\triangle}$ E

की

号

ษ

हू न ह

म1

का न का

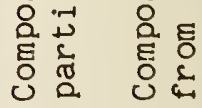

$\approx$ ○ 
Table 17. Residual Moisture Content, Brooklyn, NY

(Mass \%, As-Received Basis)a

\begin{tabular}{|c|c|c|c|c|c|}
\hline Day & 1 & 2 & 3 & 4 & 5 \\
\hline $\begin{array}{l}\text { Composite } \\
\text { sample } \\
\text { Average }\end{array}$ & $\begin{array}{l}4.39 \\
3.99 \\
4.19\end{array}$ & $\begin{array}{l}4.11 \\
3.79 \\
3.95\end{array}$ & $\begin{array}{l}4.28 \\
3.89 \\
4.09\end{array}$ & $\begin{array}{l}4.09 \\
3.78 \\
3.94\end{array}$ & $\begin{array}{l}4.27 \\
4.31 \\
4.29\end{array}$ \\
\hline $\begin{array}{l}\text { Paper, } \\
\text { unbleached } \\
\text { Average }\end{array}$ & $\begin{array}{l}4.44 \\
5.62 \\
5.03\end{array}$ & $\begin{array}{l}3.90 \\
4.25 \\
4.08\end{array}$ & $\begin{array}{l}4.01 \\
3.89 \\
3.95\end{array}$ & $\begin{array}{l}4.85 \\
\frac{4.53}{4.69}\end{array}$ & $\begin{array}{l}5.75 \\
5.21 \\
5.48\end{array}$ \\
\hline $\begin{array}{l}\text { Paper, } \\
\text { bleached } \\
\text { Average }\end{array}$ & $\begin{array}{l}4.17 \\
5.01 \\
4.59\end{array}$ & $\begin{array}{l}2.13 \\
3.91 \\
3.02\end{array}$ & $\begin{array}{l}4.07 \\
4.05 \\
4.06\end{array}$ & $\begin{array}{l}3.92 \\
4.00 \\
3.91\end{array}$ & $\begin{array}{l}4.75 \\
4.31 \\
4.53\end{array}$ \\
\hline $\begin{array}{l}\text { Plastics, soft } \\
\text { Average }\end{array}$ & $\begin{array}{l}1.83 \\
2.29 \\
2.06\end{array}$ & $\begin{array}{l}1.76 \\
\frac{1.76}{1.76}\end{array}$ & $\begin{array}{l}2.03 \\
2.03 \\
2.03\end{array}$ & $\begin{array}{l}1.45 \\
1.22 \\
1.34\end{array}$ & $\begin{array}{l}2.10 \\
1.69 \\
1.90\end{array}$ \\
\hline $\begin{array}{l}\text { Plastics, hard } \\
\text { Average }\end{array}$ & $\begin{array}{l}2.37 \\
1.17 \\
1.77\end{array}$ & $\begin{array}{l}0.87 \\
0.65 \\
0.76\end{array}$ & $\begin{array}{l}0.59 \\
0.54 \\
0.57\end{array}$ & $\begin{array}{l}1.03 \\
0.98 \\
1.01\end{array}$ & $\begin{array}{l}0.85 \\
0.88 \\
0.87\end{array}$ \\
\hline $\begin{array}{l}\text { Wood/Vegetable } \\
\text { Average }\end{array}$ & $\begin{array}{l}5.09 \\
\frac{4.57}{4.83}\end{array}$ & $\begin{array}{l}5.40 \\
5.91 \\
5.66\end{array}$ & $\begin{array}{l}5.42 \\
5.25 \\
5.34\end{array}$ & $\begin{array}{l}7.26 \\
8.77 \\
8.02\end{array}$ & $\begin{array}{l}4.95 \\
5.62 \\
5.29\end{array}$ \\
\hline $\begin{array}{l}\text { Textiles } \\
\text { Average }\end{array}$ & $\begin{array}{l}2.87 \\
2.82 \\
2.85\end{array}$ & $\begin{array}{l}3.36 \\
2.62 \\
2.99\end{array}$ & $\begin{array}{l}1.68 \\
2.65 \\
2.17\end{array}$ & $\begin{array}{l}1.88 \\
\frac{2.03}{1.96}\end{array}$ & $\begin{array}{l}0.43 \\
0.59 \\
0.51\end{array}$ \\
\hline $\begin{array}{l}\text { "Fines" } \\
\text { Average }\end{array}$ & $\begin{array}{l}1.99 \\
2.01 \\
2.00\end{array}$ & $\begin{array}{l}2.24 \\
\frac{2.60}{2.42}\end{array}$ & $\begin{array}{l}2.92 \\
\frac{2.52}{2.72}\end{array}$ & $\begin{array}{l}2.61 \\
2.28 \\
2.45\end{array}$ & $\begin{array}{l}4.35 \\
\frac{4.62}{4.49}\end{array}$ \\
\hline
\end{tabular}

as-Received Basis as a $2 \mathrm{~mm}$ particle size sample at the test laboratory. 
Table 18. Total Chlorine Content, Brooklyn, NY

(Mass \%)

\begin{tabular}{|c|c|c|c|c|c|}
\hline Day & 1 & 2 & 3 & 4 & 5 \\
\hline Composite & 1.91 & 0.59 & 0.82 & 0.63 & 1.38 \\
\hline sample & 1.91 & 0.51 & 0.85 & 0.62 & 1.15 \\
\hline & 2.10 & 0.77 & 0.68 & 0.57 & 1.39 \\
\hline Average, As Rec'da & $\overline{1.97}$ & $\overline{0.62}$ & $\overline{0.78}$ & $\overline{0.61}$ & $\overline{1.31}$ \\
\hline Average, Dry Basis & 2.06 & 0.65 & 0.82 & 0.63 & 1.37 \\
\hline Paper, & 1.07 & 0.27 & 0.05 & 0.36 & 0.73 \\
\hline unbleached & 1.01 & 0.38 & 0.25 & 0.28 & 0.70 \\
\hline & 0.82 & 0.25 & 0.20 & 0.27 & 0.40 \\
\hline Average, As Rec' $\mathrm{d}^{\mathrm{a}}$ & $\overline{0.97}$ & $\overline{0.30}$ & $\overline{0.17}$ & 0.30 & $\overline{0.61}$ \\
\hline Average, Dry Basis & 1.02 & 0.31 & 0.17 & 0.32 & 0.65 \\
\hline Paper, & 0.17 & 0.48 & 0.22 & 0.17 & 0.40 \\
\hline bleached & 0.28 & 0.32 & 0.26 & 0.28 & 0.41 \\
\hline & 0.16 & 0.38 & 0.21 & 0.16 & 0.42 \\
\hline Average, As Rec' $\mathrm{d}^{\mathrm{a}}$ & $\overline{0.20}$ & $\overline{0.39}$ & $\overline{0.23}$ & $\overline{0.20}$ & $\overline{0.41}$ \\
\hline Average, Dry Basis & 0.21 & 0.41 & 0.24 & 0.21 & 0.43 \\
\hline Plastics, soft & 3.00 & 3.21 & 7.99 & 1.79 & 1.78 \\
\hline & 3.12 & 2.76 & 7.64 & 1.97 & 1.86 \\
\hline & 3.26 & 3.12 & 8.34 & 1.96 & 1.65 \\
\hline Average, As Rec' $\mathrm{d}^{\mathrm{a}}$ & $\overline{3.13}$ & $\overline{3.03}$ & $\overline{7.99}$ & $\overline{1.91}$ & $\overline{1.76}$ \\
\hline Average, Dry Basis & 3.19 & 3.08 & 8.16 & 1.93 & 1.80 \\
\hline Plastics, hard & 7.16 & 1.51 & 5.15 & 1.35 & 6.21 \\
\hline & $7 \cdot 95$ & 1.60 & 3.91 & 1.61 & 4.66 \\
\hline & 7.95 & 1.53 & 3.52 & 1.77 & 6.42 \\
\hline Average, As Rec' $d^{a}$ & $\overline{7.69}$ & $\overline{1.55}$ & $\overline{4.19}$ & $\overline{1.58}$ & $\overline{5.76}$ \\
\hline Average, Dry Basis & 7.83 & 1.56 & 4.22 & 1.59 & 5.81 \\
\hline Wood/vegetable & 1.16 & 0.42 & 2.77 & 0.50 & 0.21 \\
\hline & 1.13 & 0.51 & 0.25 & 0.57 & 0.77 \\
\hline & 1.22 & 0.19 & 0.62 & 0.58 & 0.15 \\
\hline Average, As Rec' $d^{a}$ & $\overline{1.17}$ & $\overline{0.37}$ & $\overline{1.21}$ & $\overline{0.55}$ & 0.38 \\
\hline Average, Dry Basis & 1.23 & 0.40 & 1.28 & 0.60 & 0.40 \\
\hline
\end{tabular}


Table 18. (Continued) Total Chlorine Content, Brooklyn, NY

\section{(Mass \%)}

$\begin{array}{lccccc}\text { Day } & 1 & 2 & 3 & 4 & 5 \\ \text { Textiles } & 0.79 & 0.68 & 0.25 & 1.75 & 0.22 \\ & 0.67 & 0.55 & 0.17 & 1.95 & 0.19 \\ \text { Average, As Rec'da } & \frac{0.73}{0.73} & \underline{0.59} & \underline{0.26} & \frac{1.93}{1.88} & \frac{0.19}{0.20} \\ \text { Average, Dry Basis } & 0.75 & 0.63 & 0.23 & 1.91 & 0.20 \\ & & & & & \\ \text { "Fines" } & 6.09 & 0.51 & 0.40 & 0.61 & 1.70 \\ & 8.03 & 0.47 & 0.39 & 0.55 & 1.69 \\ \text { Average, As Rec'da } & \frac{6.19}{6.77} & \underline{0.49} & \underline{0.42} & \underline{0.60} & \frac{1.54}{0.40} \\ \text { Average, Dry Basis } & 6.91 & 0.50 & 0.41 & 0.60 & 1.72\end{array}$

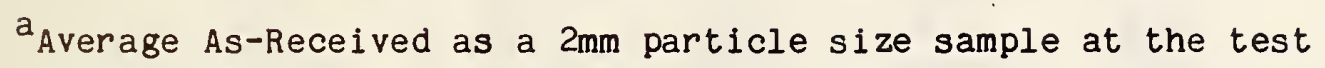
laboratory . 
Table 19. Water Soluble Chlorine Content,

\author{
Brooklyn, NY
}

(Mass \%)

\begin{tabular}{|c|c|c|c|c|c|}
\hline Day & 1 & 2 & 3 & 4 & 5 \\
\hline Composite & 0.98 & 0.10 & 0.18 & 0.17 & 0.43 \\
\hline sample & 0.59 & 0.19 & 0.12 & 0.14 & 0.31 \\
\hline & 1.13 & 0.19 & 0.11 & 0.17 & 0.42 \\
\hline Average, As-Rec'd ${ }^{a}$ & 0.90 & 0.16 & 0.14 & 0.16 & 0.39 \\
\hline Average, Dry Basis & 0.94 & 0.17 & 0.14 & 0.17 & 0.40 \\
\hline Paper, & 0.76 & 0.15 & 0.08 & 0.15 & 0.50 \\
\hline unbleached & 0.92 & 0.15 & 0.08 & 0.14 & 0.32 \\
\hline & 0.62 & 0.20 & 0.08 & 0.13 & 0.36 \\
\hline Average, As-Rec' $d^{a}$ & $\overline{0.77}$ & $\overline{0.17}$ & $\overline{0.08}$ & 0.14 & 0.39 \\
\hline Average, Dry Basis & 0.81 & 0.17 & 0.08 & 0.15 & 0.42 \\
\hline Paper, & 0.08 & 0.23 & 0.09 & 0.09 & 0.29 \\
\hline bleached & 0.08 & 0.22 & 0.06 & 0.08 & 0.30 \\
\hline & 0.04 & 0.23 & 0.08 & 0.08 & 0.29 \\
\hline Average, As-Rec' $d^{a}$ & $\overline{0.07}$ & $\overline{0.23}$ & $\overline{0.08}$ & $\overline{0.08}$ & 0.29 \\
\hline Average, Dry Basis & 0.07 & 0.23 & 0.08 & 0.09 & 0.31 \\
\hline Plastics, soft & 0.42 & 0.18 & 0.12 & 0.17 & 0.18 \\
\hline & 0.30 & 0.18 & 0.13 & 0.16 & 0.24 \\
\hline & 0.37 & 0.19 & 0.12 & 0.19 & 0.26 \\
\hline Average, As-Rec' $d^{a}$ & $\overline{0.36}$ & $\overline{0.18}$ & $\overline{0.12}$ & $\overline{0.17}$ & 0.23 \\
\hline Average, Dry Basis & 0.37 & 0.19 & 0.13 & 0.18 & 0.23 \\
\hline Plastics, hard & 0.31 & 0.06 & 0.02 & 0.05 & 0.05 \\
\hline & 0.43 & 0.09 & 0.03 & 0.03 & 0.05 \\
\hline & 0.47 & 0.09 & 0.02 & 0.04 & 0.05 \\
\hline Average, As-Rec' $\mathrm{d}^{\mathrm{a}}$ & $\overline{0.40}$ & 0.08 & $\overline{0.02}$ & 0.04 & 0.05 \\
\hline Average, Dry Basis & 0.41 & 0.08 & 0.02 & 0.04 & 0.05 \\
\hline Wood/vegetable & 0.59 & 0.26 & 0.16 & 0.25 & 0.30 \\
\hline & 0.59 & 0.27 & 0.25 & 0.21 & 0.31 \\
\hline & 0.33 & 0.16 & 0.29 & 0.22 & 0.48 \\
\hline Average, As-Rec' $\mathrm{d}^{\mathrm{a}}$ & 0.50 & 0.23 & 0.23 & 0.23 & 0.36 \\
\hline Average, Dry Basis & 0.53 & 0.24 & 0.24 & 0.25 & 0.38 \\
\hline
\end{tabular}


Table 19. (Continued) Water Soluble Chlorine Content, Brooklyn, NY

\section{(Mass \%)}

$\begin{array}{lccccc}\text { Day } & 1 & 2 & 3 & 4 & 5 \\ \text { Textiles } & 0.65 & 0.42 & 0.20 & 0.27 & 0.09 \\ & 0.60 & 0.33 & 0.13 & 0.26 & 0.09 \\ \text { Average, As-Rec'd } & \underline{0.34} & \underline{0.32} & \underline{0.13} & \frac{0.22}{0.25} & \frac{0.03}{0.07} \\ \text { Average, Dry Basis } & 0.55 & 0.36 & 0.15 & 0.25 & 0.07 \\ \text { "Fines" } & 0.65 & 0.25 & 0.27 & 0.53 & 1.50 \\ & 0.33 & 0.41 & 0.32 & 0.32 & 0.40 \\ \text { Average, As-Rec'da } & \underline{0.33} & 0.50 & 0.39 & 0.22 & 0.78 \\ \text { Average, Dry Basis } & 0.79 & 0.39 & 0.33 & 0.36 & 0.89 \\ \end{array}$

average As-Received as a $2 \mathrm{~mm}$ particle size sample at the test laboratory. 
Table 20. Sulfur Content of Composite Samples,

Brooklyn, NY

(Mass)

\begin{tabular}{lllllll} 
Day & 1 & 2 & 3 & 4 & 5 & Average \\
Sample 1 & 0.18 & 0.06 & 0.18 & 0.12 & 0.12 & \\
Sample 2 & 0.25 & 0.17 & 0.06 & 0.06 & 0.05 & \\
Sample 3 & 0.23 & 0.20 & 0.21 & 0.05 & 0.12 & \\
\hline $\begin{array}{c}\text { Average, } \\
\text { As-Rec'da }\end{array}$ & 0.22 & 0.14 & 0.15 & 0.08 & 0.10 & 0.14 \\
$\begin{array}{c}\text { Average, } \\
\text { Dry Basis }\end{array}$ & 0.23 & 0.15 & 0.13 & 0.08 & 0.10 & 0.14
\end{tabular}

A Average As-Received as a $2 \mathrm{~mm}$ particle size sample at the test laboratory. 


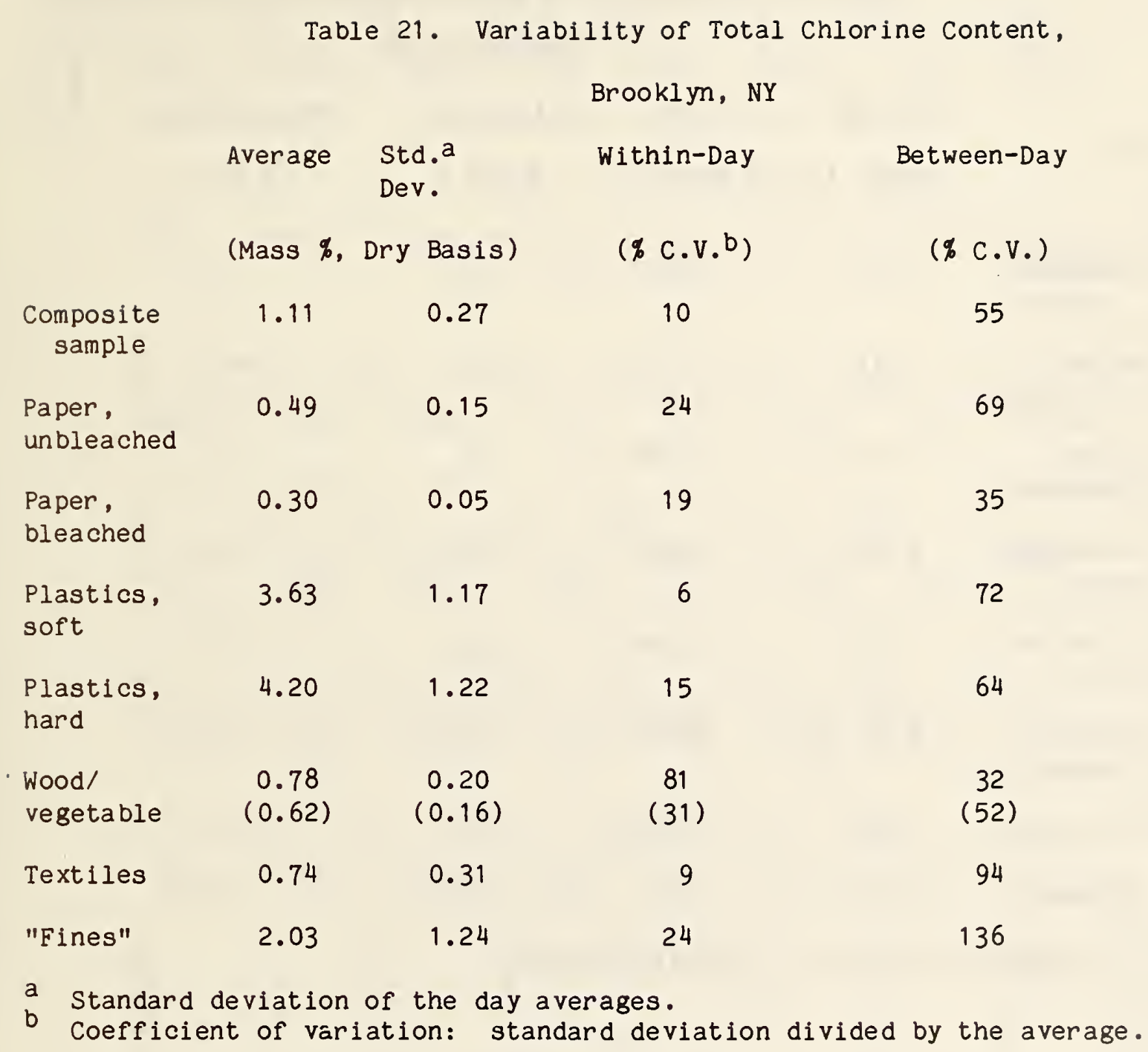


Table 22. Variability of Water Soluble Chlorine Content, Brooklyn, NY

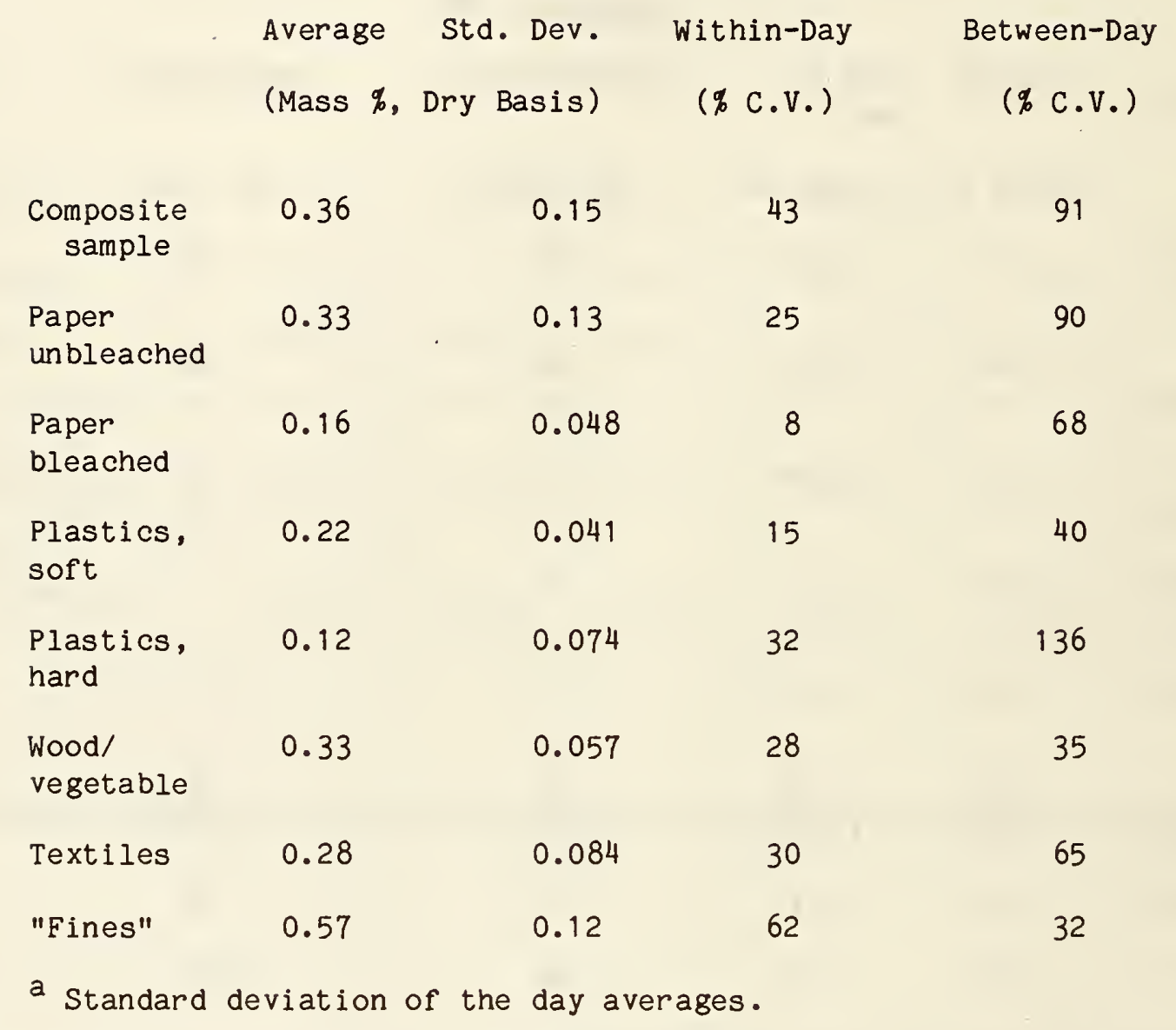


兽

(5)

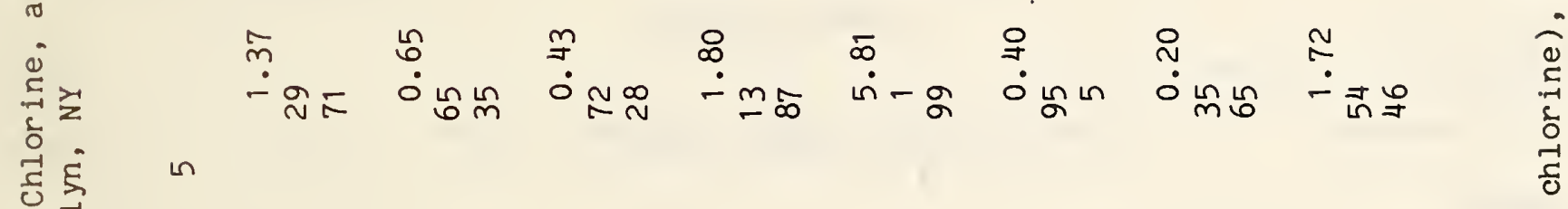

(1) $\frac{x}{0}$

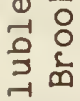

क

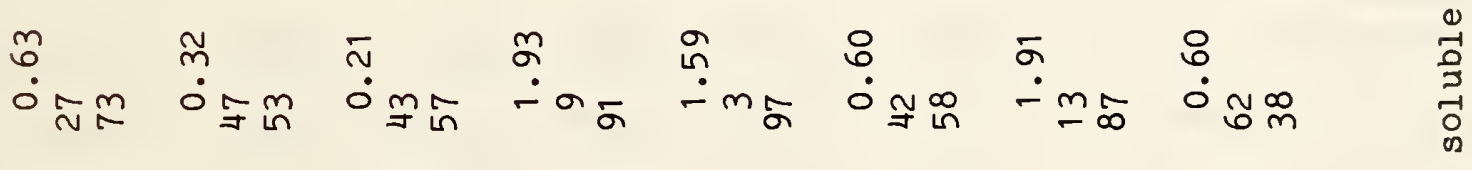

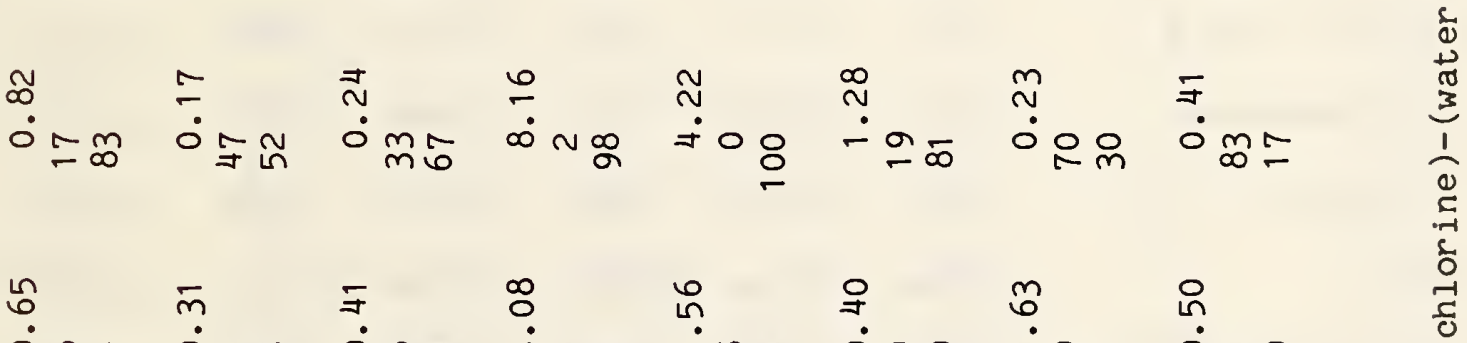

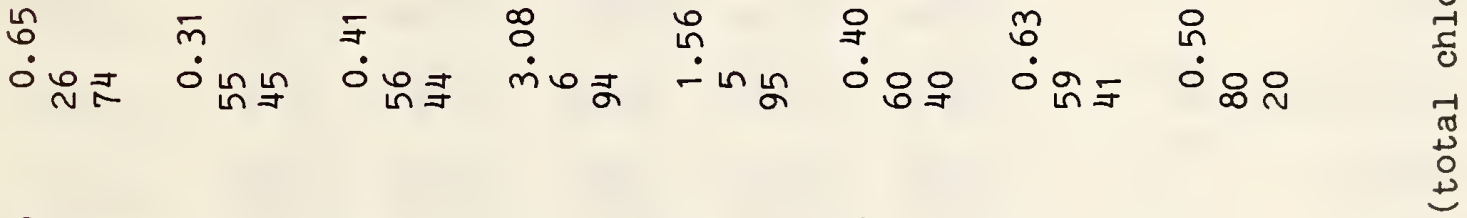

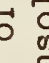

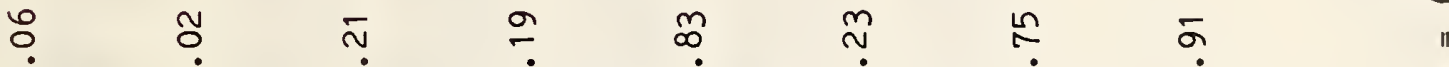

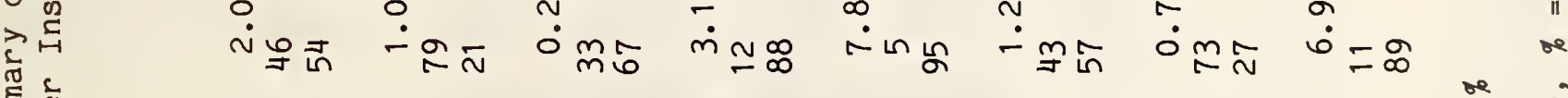

s.

$\ddot{\sim}$

ח

$\begin{array}{ll}0 & 0 \\ -1 & 0 \\ 0 & 0 \\ 0 & 0 \\ 0 & 0\end{array}$

$\begin{array}{ll}0 & 0 \\ 0 & 0 \\ 0 & 0 \\ 0 & 0 \\ 0 & 0\end{array}$

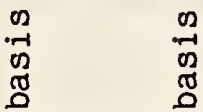

$\begin{array}{ll}0 & 0 \\ 0 & 0 \\ 0 & 0 \\ 0 & 0 \\ 0 & 0\end{array}$

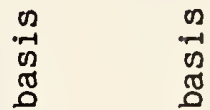

$\vec{\delta}-\vec{i}$ ते $\overrightarrow{0}$ के $\overrightarrow{0}$

रำ

- $-1, \frac{1}{2}$

व

भू

จ न

बह त्र

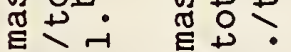

की

क त

\&

里

बै

क त

de तु de तु

$\pi$.

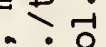

$\pi$.

ए

ก)

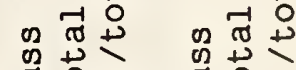

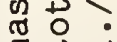

हैं

눙

-iं

ન્ઠ

당 돌

ना नी

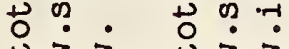

मै ?.

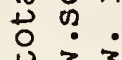

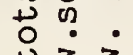

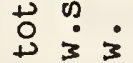

तี नु क

मै०

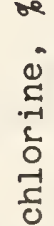

se

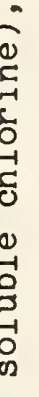

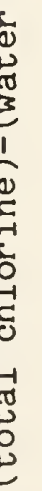

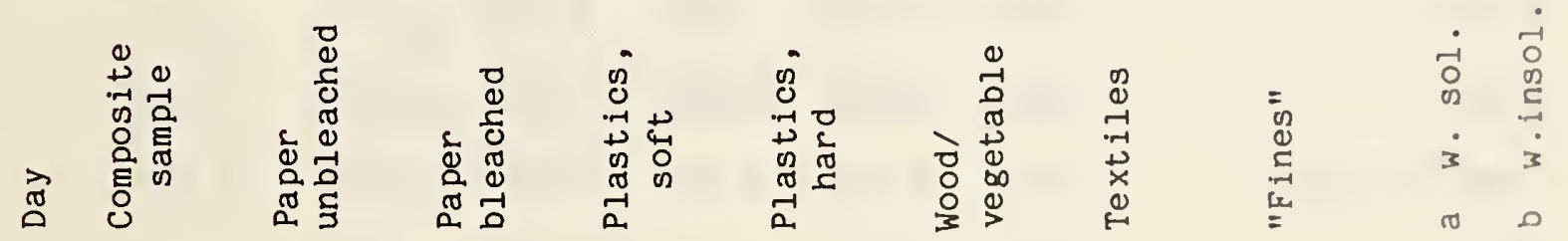


Table 24. Amount of Chlorine Contributed by MSW Components, Brooklyn, NY (Mass \%, Dry Basis)

Day

1

2

34

5 Average

Std. Dev.

Total Chlorine

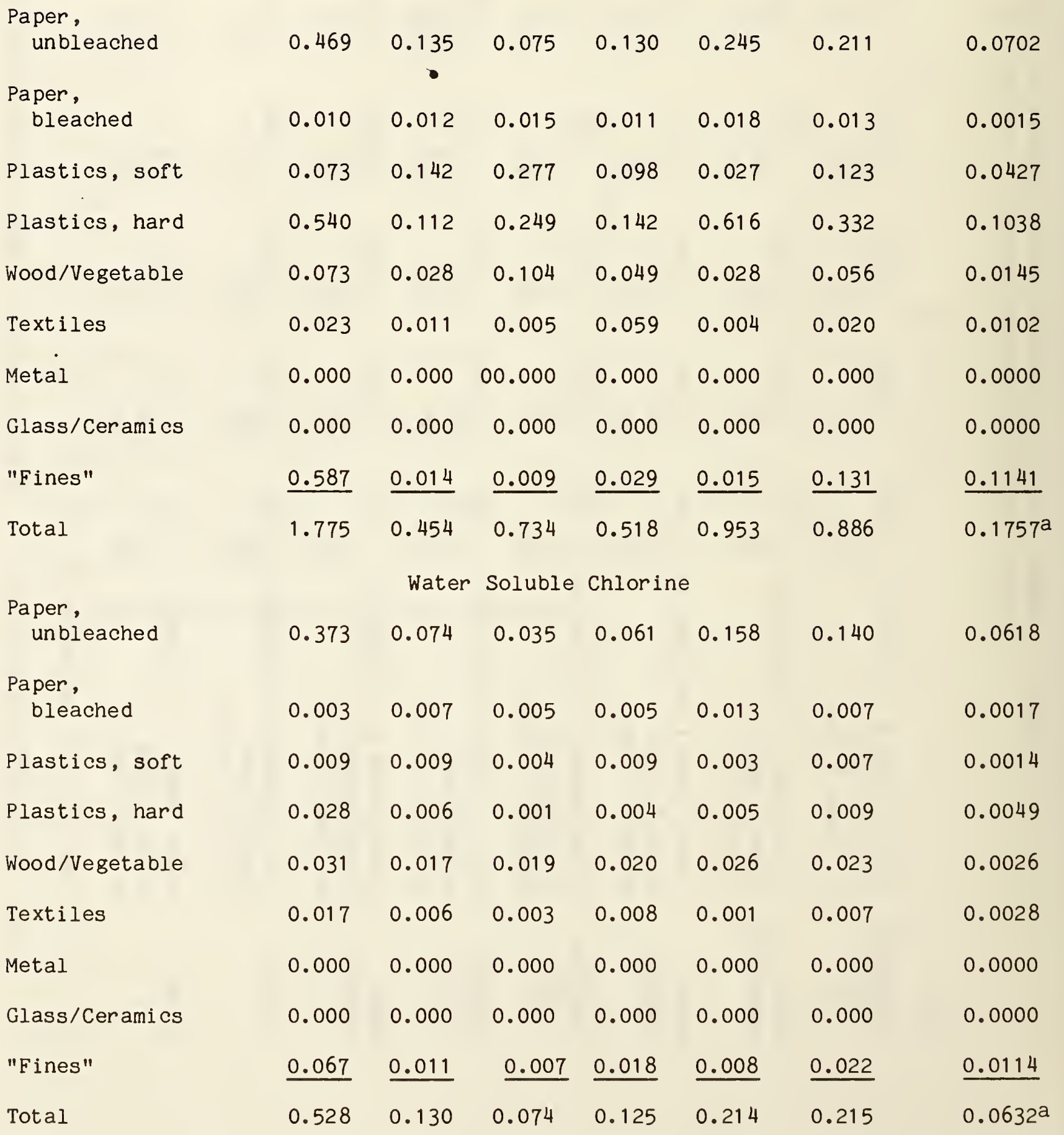


Table 24. (Continued) Amount of Chlorine Contributed by MSW Components, Brooklyn, NY

(Mass \%, Dry Basis)

\begin{tabular}{|c|c|c|c|c|c|c|c|}
\hline Day & 1 & 2 & 3 & 4 & 5 & Average & $\begin{array}{l}\text { std. Dev. } \\
\text { of the Ave }\end{array}$ \\
\hline & & Water & [nsolub & \multicolumn{4}{|c|}{ Chlorine } \\
\hline $\begin{array}{l}\text { Paper, } \\
\text { unbleached }\end{array}$ & 0.096 & 0.061 & 0.040 & 0.069 & 0.087 & 0.071 & 0.0935 \\
\hline $\begin{array}{l}\text { Paper, } \\
\quad \text { bleached }\end{array}$ & 0.007 & 0.005 & 0.010 & 0.006 & 0.005 & 0.007 & 0.0023 \\
\hline Plastics, soft & 0.064 & 0.133 & 0.273 & 0.089 & 0.024 & 0.117 & 0.0427 \\
\hline Plastics, hard & 0.512 & 0.106 & 0.248 & 0.138 & 0.611 & 0.323 & 0.1039 \\
\hline Wood/Vegetable & 0.042 & 0.011 & 0.085 & 0.029 & 0.002 & 0.034 & 0.0147 \\
\hline Textile & 0.006 & 0.005 & 0.002 & 0.051 & 0.003 & 0.013 & 0.0106 \\
\hline Metal & 0.000 & 0.000 & 0.000 & 0.000 & 0.000 & 0.000 & 0.0000 \\
\hline Glass/Ceramics & 0.000 & 0.000 & 0.000 & 0.000 & 0.000 & 0.000 & 0.0000 \\
\hline "Fines" & 0.520 & 0.003 & 0.002 & $\underline{0.011}$ & $\underline{0.007}$ & 0.109 & 0.1147 \\
\hline Total & 1.247 & 0.324 & 0.660 & 0.393 & 0.739 & 0.674 & $0.1867^{b}$ \\
\hline
\end{tabular}

The square root of the sum of squares of the standard deviations of the averages for each component of MSW listed in the column above.

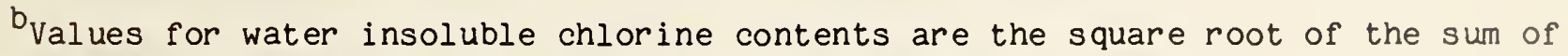
squares of the standard deviations of the averages for the total chlorine and water soluble chlorine values for individual components.

Note: Conversion from a dry basis to an as-received basis at the facility can be made by multiplying the mass \% dry basis in table 12 by (100 - \% total molsture (table 15))/100 for daily or average values. For example, the average total chlorine content is 0.886 mass $\%$, dry basis; $(0.886)(100-16.0) / 100=0.744$ or 0.74 mass $\%$, as received at the facility. 

Table 25. Calculated Percent of Chlorine Contributed by Components of Brooklyn MSW to Chlorine Content

(Percent of sum of components for each day, dry initial composition)

Day

1
2

Total Chlorine Content

Paper, unbleached 26

Paper, bleached 1

Paper, total

27

Plastics, soft

4

Plastics, hard

30

Plastics, total

34

Wood/vegetable

Textiles

"Fines"

34

4

1

34

Water Soluble Chlorine Content

Paper, unbleached 71

57

47

49

74

65

Paper, bleached

0

Paper, total

71

5

62

7

54

5

Plastics, soft

2

Plastics, hard

5

Plastics, total

7

6

Wood/vegetable

Textiles

3

"Fines"
7

5

12

13

5

8
25

2

27

19

28

47

9

11

6

1
15

24

1

25

14

38

52

6

2 
Table 25. (Continued) Calculated Percent of Chlorine Contributed by Components of Brooklyn MSW to Chlorine Content

(Percent of sum of components for each day, dry initial composition)

Day

1

2

3

4

$5 \quad$ Average

Water Insoluble Chlorine Content

Paper, unbleached

19

6

18

12

11

Paper, bleached

2

2

2

1

1

Paper, total

9

2

20

13

12

Plastics, soft

5

40

22

3

17

Plastics, hard

41

33

38

35

83

48

Plastics, total

46

73

79

57

86

65

Wood/vegetable

3

3

13

7

0

5

Textiles

0

2

13

0

2

"Fines"

42

1

0

3

16 
4. TITLE AND SUBTITLE

The Chlorine Content of Municipal Solid Waste from Baltimore County, MD and Brooklyn, NY

5. $\operatorname{AUTHOR}(S)$

K.L. Churney, A.E. Ledford, Jr., S.S. Bruce, and E.S. Domalski

6. PERFORMING ORGANIZATION (If joint or other than NBS, see instructions)

NATIONAL BUREAU OF STANDARDS

DEPARTMENT OF COMMERCE

WASHINGTON, D.C. 20234

9. SPONSORING ORGANIZATION NAME AND COMPLETE ADDRESS (Street, City, Stote, ZIP)

Uffice of Renewable Technology, Energy from Municipal Waste Division, U.S. Department of Energy, Washington, D.C., and

Department of Sanitation, Office of Resource Recovery and Waste Disposal Planning The City of New York, New York.

10. SUPPLEMENTARY NOTES

[ Document describes a computer program; SF-185, FIPS Software Summary, is attached.

11. ABSTRACT (A 200-word or less foctual summary of most significant informotion. If document includes a significant bibliogrophy or literoture survey. mention it here)

The total chlorine and water soluble chlorine contents of the components of municipal solid waste (MSW) have been determined from sampling studies carried out at two sites, Baltimore County, MD and Brooklyn, NY for a five-day period. The total chlorine contents of the overall MSW samples at Baltimore County, MD and Brooklyn, NY are 0.45 and 0.89 mass $\%$, respectively.

The component which contributed the largest fraction to the chlorine content in Baltimore County, MD was the paper fraction $(0.25$ mass $\%$ or $55 \%$ of the total chlorine) while in Brooklyn, NY, the plastics fraction provided the major contribution ( 0.46 mass $\%$ or $52 \%$ of the total chlorine). Chemical analyses for sulfur content were performed on composite samples for each day of sampling at the two sites. The suifur contents found in composite samples representing Baltimore County, MD and Brooklyn, NY were 0.13 and 0.14 mass $\%$, respectively. American Society for Testing and Materials (ASTM) standard methods for sulfur, total chlorine, and water soluble chlorine contents, developed for refuse-derived fuel, were used in performing the analyses.

All values mentioned above in mass $\%$ are on a dry basis.

12. KEY WORDS (Six to twelve entries; alphabetical order: capitalize only proper names: and separate key words by semicolons) chlorine anaīysis; municipal solid waste; sample size reduction; sampling; sorting; total chlorine content; water insoluble chlorine; water soluble chlorine.

13. AVAILABILITY

[X] Unlimited

For Official Distribution. Do Not Release to NTIS

[.] Order From Superintendent of Documents, U.S. Government Printing Office, Washington. D.C. 20402.

14. NO, OF

PRINTED PAGES

$$
62
$$

15. Price

[X] Order From National Technical Information Service (NTIS), Springfield, VA. 22/6I 


